\title{
Geochemical characterization and isotopic age of Caradocian magmatism in the northeastern Iberian Peninsula: Insights into the Late Ordovician evolution of the northern Gondwana margin
}

\author{
Marina Navidad ${ }^{\text {a,* }}$, Pedro Castiñeiras a , Josep M. Casas ${ }^{\text {b }}$, Montserrat Liesa a, Javier Fernández Suárez a , \\ Antoni Barnolas ${ }^{c}$, Jordi Carreras ${ }^{\mathrm{e}}$, Inmaculada Gil-Peña ${ }^{\mathrm{c}}$ \\ a Departamento de Petrología y Geoquímica-Instituto de Geologín Económica (CSIC) Universidad Complutense de Madrid, José Antonio Novais 2, Madrid, 28040, Spain \\ ${ }^{b}$ Departament de Geodinamica $i$ Geofisica-Institut de recerca GEMODELS, Universitat de Barcelona, Martí $i$ Franquès $s / n$, Barcelona, 08028, Spain \\ ' Instituto Geológico y Minero de España, Ríos Rosas 23, Madrid, 28003, Spain \\ a Departament de Geoquimica, Petrologia $i$ Prospecció Geologica, Universitat de Barcelona, Martí $i$ Franquès $s / n, B a r c e l o n a, 08028,5 p a i n$ \\ e Departament de Geologia, Universitat Autònoma de Barcelona, Bellaterra (Cerdanyola del Vallès), 08193, Spain
}

\section{Keywords:}

Metaluminous and aluminous orthogneisses Pyroclastic calc-alkaline metavolcanic rocks Geochemistry

$\mathrm{Sr}-\mathrm{Nd}$ isotopes

$\mathrm{U}-\mathrm{Pb}$ dating

Late Ordovician magmatism

Northeastern Iberia

\begin{abstract}
A B S T R A C T
This paper presents new geochronological, geochemical and isotopic data for late Ordovician magmatism ( $455 \pm 2 \mathrm{Ma}$ ) from the Variscan massifs in the northeastern Iberian Peninsula. This magmatism is mainly composed of aluminous and metaluminous plutonic rocks and a sequence of calc-alkaline ignimbrites and epiclastic volcanic rocks, which were deformed and metamorphosed during the Variscan orogeny. The metaplutonic rocks are located in the lower part of a Neoproterozoic/Early Cambrian metasedimentary sequence in the Canigó massif (Eastern Pyrenees). Aluminous orthogneisses have isotopic signatures that indicate a crustal origin, whereas metaluminous orthogneisses originate from a mixture of juvenile and crustal melts. The metavolcanic rocks define a calc-alkaline ignimbritic sequence of crustal origin located in the lower part of the Late Ordovician sequence in the Les Gavarres massif (Catalan Coastal Ranges). $T_{\mathbf{M}}$ ages for all the studied Late Ordovician rocks range from Mesoproterozoic to Paleoproterozoic $(1.3 \mathrm{Ga}, 1.5 \mathrm{Ga}$, $1.7 \mathrm{Ga}$ and $2.2 \mathrm{Ga}$ ), suggesting a Neoproterozoic crust with Paleoproterozoic components and an arc signature, as the most probable source for the crustal melts. The isotopic similarities between the studied samples and other Early Ordovician magmatic rocks of the Central and Western Iberian Massif suggest repeated melt extractions from a common basement as the source for the Early and Late Ordovician magmatism in the Iberian realm. However, the studied massifs are more closely linked to other massifs from the Mediterranean realm. The most probable tectonic setting for the emplacement of the Late Ordovician volcanic and plutonic bodies is that of an extensional regime, which postdates a previous Ordovician contractional event and the opening of the Rheic Ocean.
\end{abstract}

\section{Introduction}

Variscan rocks that crop out in northeastern Iberia are concentrated in two areas: the Pyrenees and the Catalan Coastal Ranges (Fig. 1). The pre-Silurian succession of these areas consists of an up to $5000 \mathrm{~m}$ thick sequence that contains records of three different magmatic episodes: a Late Neoproterozoic-Early Cambrian event, an Early Ordovician event and a Late Ordovician event. The Late Neoproterozoic-Early Cambrian magmatism gave rise to small bodies of metaluminous and aluminous granitoids and syn-sedimentary

\footnotetext{
* Corresponding author. Fax: + 34915222535

E-mail address: navidad@geo.ucm.es (M. Navidad).
}

bimodal volcanic rocks interbedded in the lower part of an upper Neoproterozoic-lower Cambrian sequence (Cocherie et al., 2005; Castiñeiras et al., 2008). This magmatism resulted from the continued oblique subduction of the Iapetus or Prototethys oceans under the northern Gondwana margin from the Late Neoproterozoic to Early Cambrian, (Chen et al., 2000; Crowley et al., 2000; Fernández-Suárez et al., 2000; Finger et al., 2000; Murphy et al., 2008a,b).

The Early-mid-Ordovician magmatic episode emplaced large bodies of aluminous granites into the middle part of the pre-Silurian sequence (Deloule et al., 2002; Cocherie et al., 2005; Castiñeiras et al., 2008), although minor sub-volcanic bodies have also been identified (Liesa et al., in press). This event, which is related to the break-up of the northern Gondwana margin, is widely exposed in other areas of the European Variscides, where it has been the subject of numerous studies (e.g. Pin and Marini, 1993; von Raumer, 1998; Helbing and Tiepolo, 2005; Casini and Oggiano, 2008; Melleton et al., 2010). 


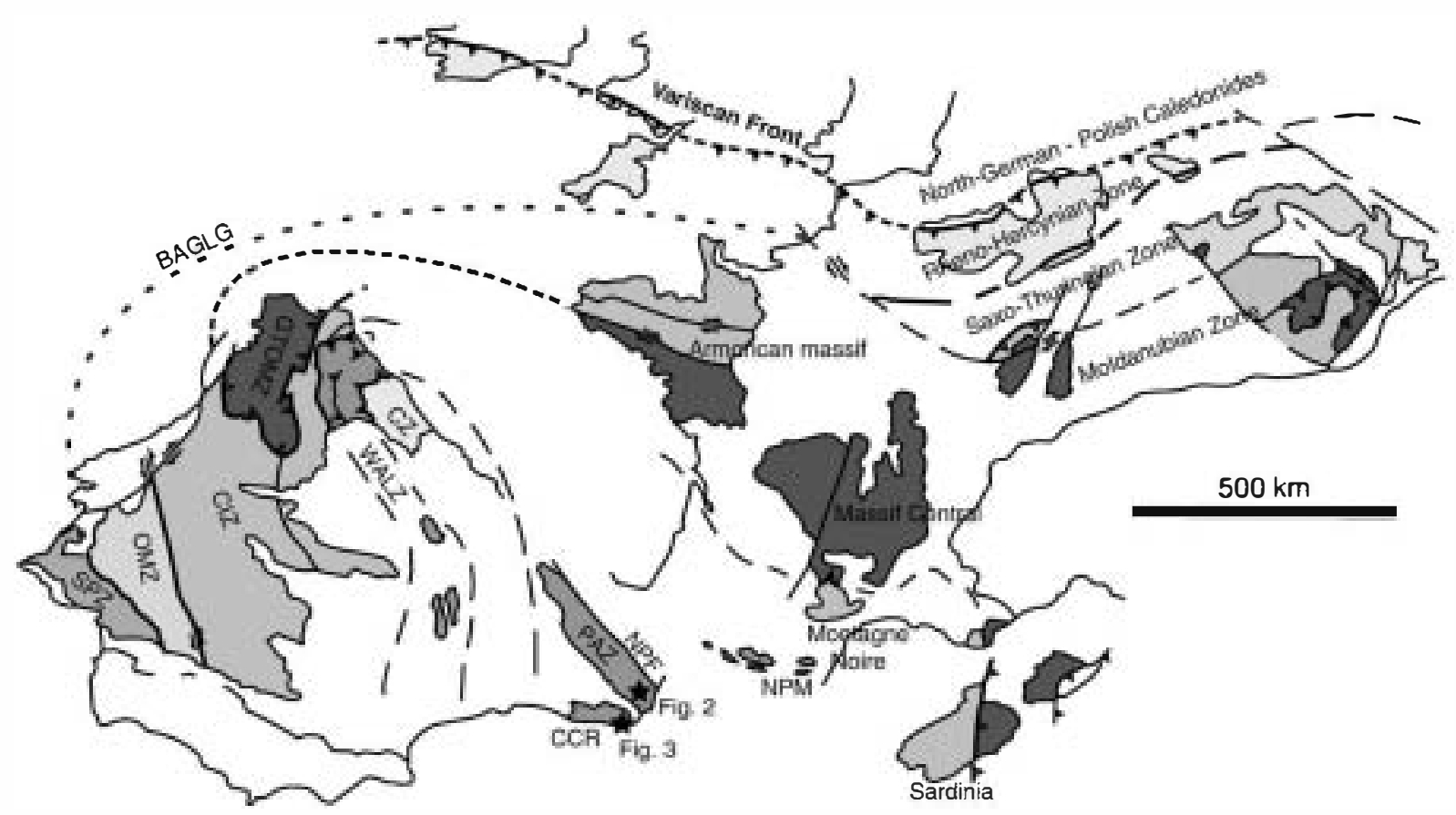

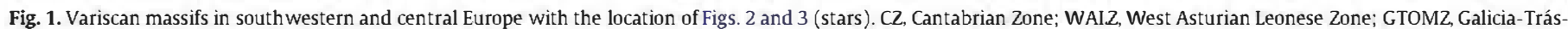

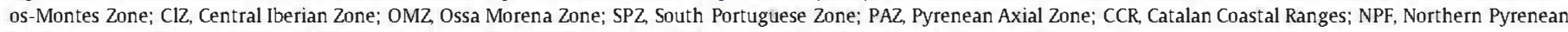
Fault; NPM, North Pyrenean Massifs; BAGLG, Beja-Acebuches-Galicia-Lizard-Giesen oceanic suture Zone. After Robardet (2002).

The Late Ordovician magmatic event is represented mainly by calcalkaline ignimbrites, andesites, volcaniclastic rocks, diorites and various types of granitic bodies. This magmatism is well known in the Catalan Coastal Ranges (Navidad and Barnolas, 1991; Barnolas and Garcia-Sansegundo, 1992) and the Pyrenees (Robert and Thiebaut, 1974; Martí et al., 1986; Calvet et al., 1988), where it is coeval with normal fault development. The event postdates a mid-(?) Ordovician phase of folding that accounts for an Upper Ordovician unconformity (Casas and Fernández, 2007; Casas, in press). Recent data (SHRIMP U$\mathrm{Pb}$ in zircon) provide Iate Ordovician ages for the protolith of several orthogneisses in the Pyrenees (Casas et al., 2010-this issue). However, the volcanic rocks have not yet been dated, and detailed geochemical data for the volcanic and plutonic rocks are scarce.

In this paper, we present new petrographic, geochemical, geochronological and isotopic data for Late Ordovician magmatic rocks of the Pyrenees (Canigó massif) and the Catalan Coastal Ranges (Les Gavarres massif). We discuss the significance of this magmatic event in relation to the Upper Ordovician magmatism of surrounding areas in order to elucidate the evolution of this portion of the periGondwana margin and the Rheic Ocean during the Late Ordovician.

\section{Geological framework}

\subsection{Canigó massịf}

The Canigo massif exposes one of the most complete pre-Silurian sequences of the Pyrenees (Fig. 2a). A thick (up to $3000 \mathrm{~m}$ ) aluminous metagranitic body, the Canigó gneiss (Guitard, 1970), derived from an Early Ordovician intrusion (Deloule et al., 2002; Cocherie et al., 2005) divides the sequence into two parts (Fig. $2 \mathrm{~b}$ and c).

The lower series, underlying the gneiss, is up to $1500 \mathrm{~m}$ thick and comprises a succession of mica schists with marble, quartzite and metabasite intercalations (Balaig series; Guitard, 1953). The basal part of the sequence, which records high-grade metamorphic conditions (sillimanite-K-feldspar zone), is exposed in the central part of the massif because of a set of Neogene normal faults that crosscut the massif (Fig. 2b). The Casemi gneiss (Guitard, 1970) constitutes the most significant metaigneous intercalation in the Balaig series (Fig. 2c). It is a tabular body up to $1000 \mathrm{~m}$ thick mainly made up of fine-grained biotitic and amphibolic granitic gneisses. Previous geochronological data provide an age of $425 \pm 18 \mathrm{Ma}$ ( $\mathrm{Pb}$ evaporation method on single zircon, Delaperrière and Soliva, 1992), but to date no other Silurian ages for magmatism have been found in the pre-Variscan rocks of the Pyrenees. Recent geochronological data indicates a Late Ordovician age for the protolith of this orthogneiss $(445.9 \pm 4.8$ and $451.6 \pm 4.8 \mathrm{Ma} \mathrm{Ma}$, SHRIMP U-Pb in zircon, Casas et al., 2010-this issue). The Marialles metadiorite, which comprises metre-scale thick bodies interlayered in the Balaig mica schists, also yields a Late Ordovician age for the formation of its protolith ( $453 \pm 4.4 \mathrm{Ma}$, SHRIMP U-Pb in zircon, Casas et al, 2010-this issue). The structurally lowest unit recognized in the Canigó massif is the Cadí gneiss (Guitard, 1970), which crops out beneath the Balaig series (Fig. 2c). It is an aluminous metagranitic body with lithological characteristics similar to those of the Canigó gneiss, although recent geochronological data provide a Late Ordovician age for its protolith (456.1 $\pm 4.8 \mathrm{Ma}$, SHRIMP U-Pb in zircon, Casas et al., 2010this issue).

The upper sequence, overlying the Canigó gneiss, is up to $3000 \mathrm{~m}$ thick and is mainly composed of metapelites and metagreywackes interbedded with numerous layers of marbles, quartzites and calcsilicates at their base (Canavelles series of Cavet, 1957). It includes syn-sedimentary bimodal metavolcanic rocks (Ayora and Casas, 1986; Navidad and Carreras, 2002), which have yielded Late Neoproterozoic-Early Cambrian ages (SHRIMP U-Pb in zircon; $581 \pm 10 \mathrm{Ma}$, Cocherie et al., 2005; $540 \mathrm{Ma}$, Castiñeiras et al., 2008). In its upper part, this sequence consists of a monotonous succession of shales and sandstones that is of unknown age due to its unfossiliferous character, but which has been classically assigned to the Cambro-Ordovician (Cavet, 1957). An erosive angular unconformity (Fig. 2c) separates the upper sequence from a well-dated Upper Ordovician succession (Cavet, 1957; Hartevelt, 1970; Santanach 1972; García-Sansegundo et al., 2004; Casas and Fernández, 2007) that includes syn-sedimentary calc-alkaline metavolcanic rocks of crustal origin (Cavet, 1957; Hartevelt, 1970; Robert and Thiebaut, 1976, Muñoz et al., 1983; Martí et al., 1986). 


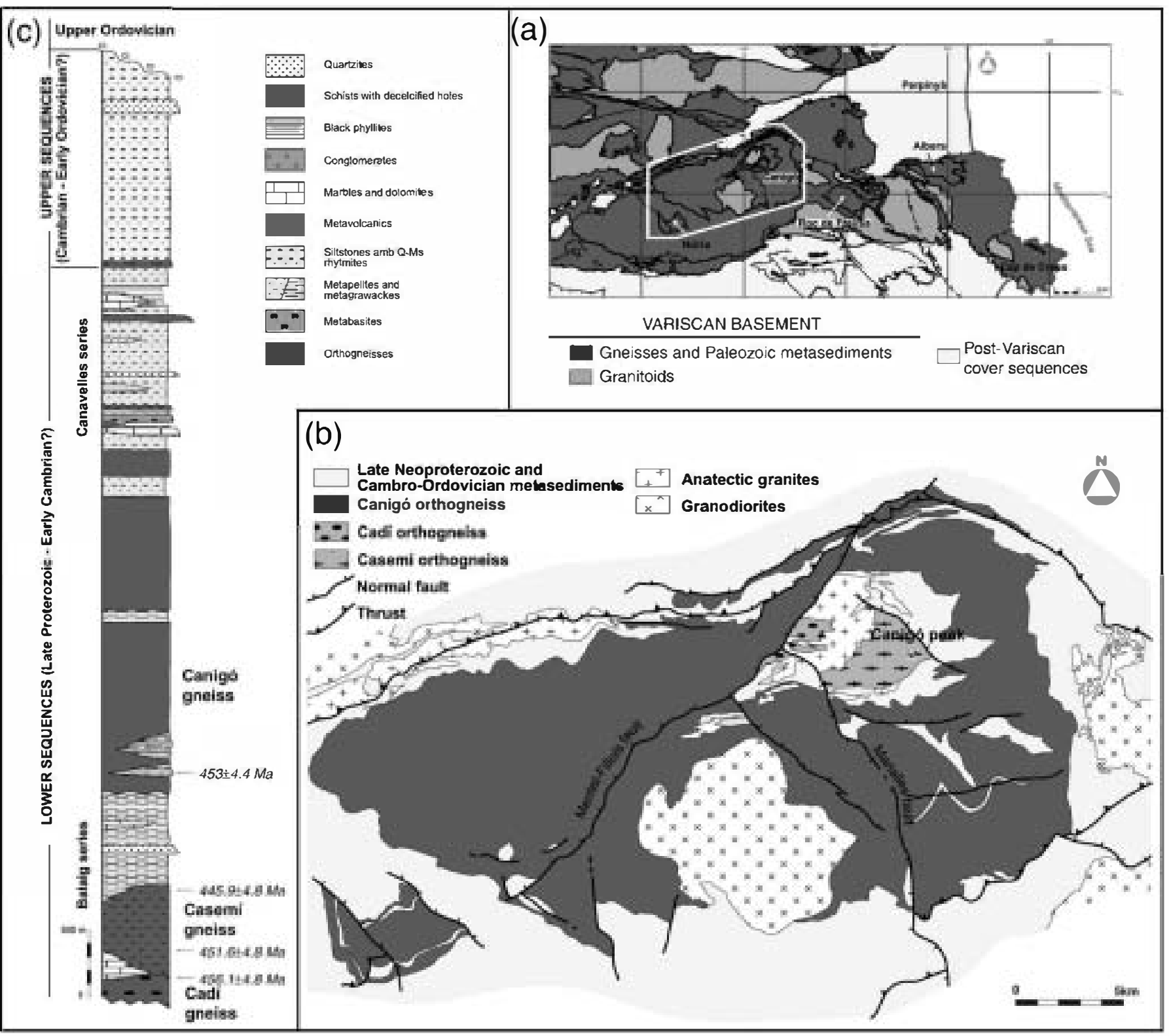

Fig. 2. (a) Geological sketch map of the Variscan basement and cover sequences in the Eastern Pyrenees. (b) Geological map of the Canigó massif. Modified after Guitard (1970), Santanach (1972), Casas (1984), and Ayora and Casas (1986). (c) Synoptic stratigraphic column of the pre-Upper Ordovician rocks of the Canigó massif. Data modified after Guitard (1970), Santanach (1972), Casas (1984), Ayora and Casas (1986) and Casas et al. (2010-this issue).

\subsection{The Catalan Coastal Ranges}

In the Catalan Coastal Ranges, the lower part of the pre-Upper Ordovician sequence is made up of a $2000 \mathrm{~m}$ thick heterogeneous succession of metapelites with intercalations of marble, quartzite, felsic gneiss and amphibolite (Fig. 3a). A Cambro-Ordovician age has been assigned to this succession (Barnolas and García-Sansegundo, 1992; Julivert and Durán, 1992) and U-Pb dating of the metaigneous rocks has yielded an Early Ordovician age (464 and $475 \mathrm{Ma}$, respectively; Gebauer, 1993). The upper part of the pre-Upper Ordovician sequence consists of a rhythmic shale series in which a Dobrotivian (early Late Ordovician) fossil assemblage has been described (Gutiérrez Marco et al., 2003). The Upper Ordovician sequence unconformably overlies the pre-Upper Ordovician sequence with a basal conglomeratic unit (Barnolas and García-Sansegundo, 1992) that exhibits similar lithological characteristics to those of the Central and Eastern Pyrenees. The conglomerates are overlain by the Els Metges unit, a succession of ignimbrites and epiclastic metavol- canic rocks up to $300 \mathrm{~m}$ thick (Navidad and Barnolas, 1991; Barnolas and Garcia-Sansegundo, 1992). In the upper part of this unit, greywackes with an important volcanic component are located on top of the volcanic section. In other massifs of the Catalan Coastal Range, the greywackes contain a brachiopod faunal assemblage of Caradoc-Ashgill age (Villas et al., 1987). A sedimentary sequence (Mas Cals unit, Fig. 3b) composed of calcareous siltstones with limestones in its lower part overlies the Els Metges unit (Barnolas and Garcia-Sansegundo, 1992). The abundant fossil content of the Mas Cals unit allows it to be assigned an Ashgillian age (Sarmiento et al., 1995).

Late Visean to Serpukhovian polyphase Variscan deformation accompanied by high temperature-low pressure metamorphism affects the entire succession (Guitard, 1970; Zwart, 1979). A pervasive fold-related crenulation cleavage is the main Variscan deformational structure in the pre-Silurian rocks (Guitard, 1962; Hartevelt, 1970; Santanach, 1972), whereas south-directed thrust sheets are well developed in the overlying Silurian, Devonian and Carboniferous 


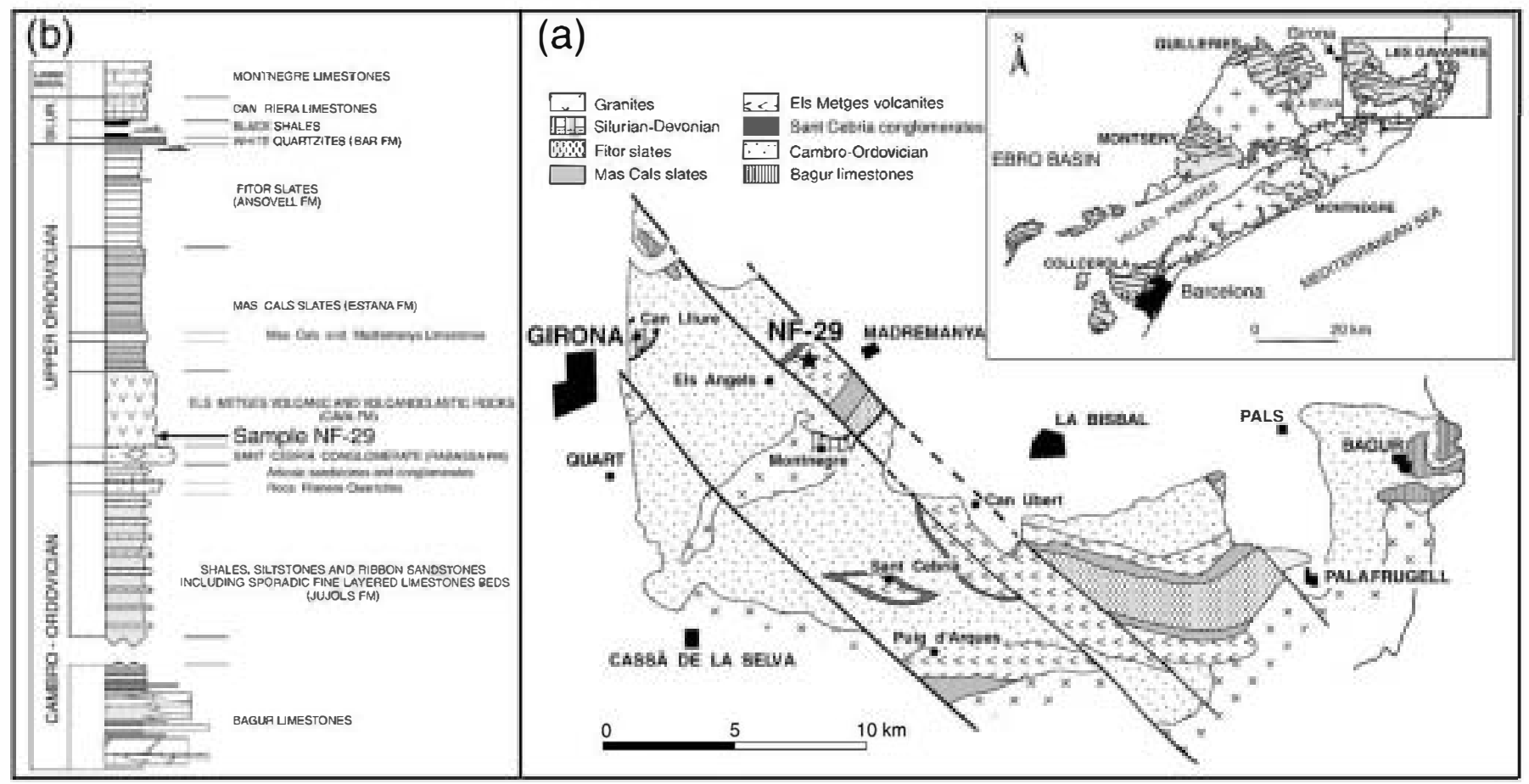

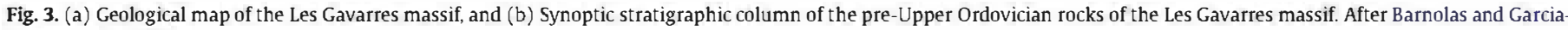
Sansegundo (1992)

successions (Hartevelt, 1970; Domingo et al., 1988; Casas et al., 1989). Infra-Silurian rocks are affected by thrusts, but these are scarce. The thrusts cut the fold-related crenulation cleavage, but are themselves folded by south-verging cleavage-related folds. Thus, thrust and fold development are broadly synchronous. Syn- to late-orogenic (Moscovian-Kasimovian, Romer and Soler, 1995) granitoids are intruded mainly into the upper levels of the succession, producing local contact metamorphism (Autran et al., 1970).

\section{Field relations and petrographic data}

\subsection{The Casemi and Cadi orthogneisses}

The Casemi orthogneiss is a deformed tabular body intercalated in the Balaig mica schists. Together with the Cadi orthogneiss and several metadiorite bodies, it represents the structurally lowest metaigneous rock recognized in the Canigó massif (Fig. 2c). Both the Canigó massif and the Casemi gneiss exhibit a dome-like structure because of the interference of two Late Variscan folding episodes and/ or because of a fold linked to an underlying Alpine thrust. The Casemí orthogneiss forms the highest relief of the massif, and its best outcrops are located around Canigó peak (Fig. 2b). To the north, the base of the body is made up of felsic and biotitic orthogneisses that gradually change to amphibolic orthogneiss to the south. The Balaig mica schists are the host rocks and exhibit different metamorphic conditions at their lower and upper contacts (sillimanite-K-feldspar and andalusite zones, respectively). The Casemí biotitic orthogneiss shows a metamorphic paragenesis made up of quartz, microcline, biotite, albite-rich plagioclase and garnet, with muscovite, epidote and titanite as retrograde minerals. The amphibolic orthogneiss is mainly composed of Fe-hornblende and plagioclase $\left(A n_{35-40}\right)$, whereas biotite and $\mathrm{K}$-feldspar are present in the transitional facies to biotitic orthogneiss. Zircon, apatite and allanite are the main accessory minerals. Both orthogneiss types show an elongated granoblastic texture. The Marialles metadiorite crops out as a thin discontinuous layer interbedded in the Balaig metasediments along the southern contact of the Casemi gneiss. It shows a metamorphic paragenesis composed of plagioclase (oligoclase), Fe-hornblende.

The Cadi orthogneiss (Fig. 2c) is located in the structurally lowest and more metamorphic layers of the Balaig series (sillimanite-Kfeldspar). It exhibits a porphyroclastic texture with a pervasive foliation. The mineral paragenesis is made up of quartz, biotite, plagioclase and $\mathrm{K}$-feldspar.

\subsection{Els Metges volcanic sequence}

In Les Gavarres massif, the felsic volcanic and volcaniclastic rocks overlie the basal conglomerates of the Upper Ordovician sequence (Fig. 3b). Volcanic rocks are rhyodacitic tuffs and massive rhyolites with well preserved relic magmatic structures such as flow lamination in the ash beds, pumice shards, U-, V- and T-shaped glass shards, and perlitic and spherulitic textures. Pseudomorphs after the mafic minerals, embayed textures in quartz, and feldspar, apatite and ilmenite phenocrysts are also abundant in the tuff. The epiclastic ash beds differ significantly from the rhyodacitic tuff with the presence of numerous fragments of prismatic quartz, metamorphic rocks, oxidewelded quartz and albite spherulites in the matrix. The volcanic rocks consequently provide ample evidence of their phreato-magmatic origin.

\section{U-Pb zircon dating}

Zircon grains from the Els Metges pyroclastic tuff (sample NF-29) were dated by U-Pb ID-TIMS (isotope dilution-thermal ionization mass spectrometry) (Table 1). As noted above, zircons from the Casemí and Cadí orthogneisses and a metadiorite body were recently dated by SHRIMP U-Pb by Casas et al. (2010-this issue).

$\mathrm{U}-\mathrm{Pb}$ analytical work for sample NF-29 was carried out at the Institute of Geology, University of Oslo, Norway. Zircon grains selected for analysis were intensely air-abraded, producing a ca. 40 to $60 \%$ reduction in grain size. The abraded zircon grains were washed in $4 \mathrm{~N}$ $\mathrm{HNO}_{3}$ on a hot plate and rinsed repeatedly with $\mathrm{H}_{2} \mathrm{O}$ and acetone (with ultrasonication after each rinsing step). After washing and 


\begin{tabular}{|c|c|c|c|c|c|c|c|c|c|c|c|c|c|c|}
\hline \multirow{3}{*}{$\begin{array}{l}\text { Sample, } \\
\text { analysis }\end{array}$} & \multirow{3}{*}{$\begin{array}{l}\text { Weight }^{\mathrm{a}} \\
{[\mu \mathrm{g}]}\end{array}$} & \multirow{3}{*}{$\begin{array}{l}\mathrm{U} \\
\text { [ppm] }\end{array}$} & \multirow{3}{*}{$\begin{array}{l}\mathrm{Th} / \\
\mathrm{U}^{\mathrm{b}}\end{array}$} & \multirow{3}{*}{$\begin{array}{l}\mathrm{Pbcom}^{\mathrm{C}} \\
{[\mathrm{pg}]}\end{array}$} & \multirow{3}{*}{$\frac{{ }^{26} \mathrm{~Pb}^{\mathrm{d}}}{{ }^{2} \mathrm{~Pb}}$} & \multirow{3}{*}{$\frac{{ }^{26} \mathrm{~Pb}^{e}}{{ }^{238} \mathrm{U}}$} & \multirow{3}{*}{$\begin{array}{l}2 \sigma^{f} \\
{[a b s]}\end{array}$} & \multirow{3}{*}{$\frac{{ }^{27} \mathrm{~Pb}}{{ }^{235} \mathrm{U}}$} & \multirow{3}{*}{$\begin{array}{l}2 \sigma \\
{[\mathrm{abs}]}\end{array}$} & \multirow{3}{*}{$\frac{{ }^{207} \mathrm{~Pb}}{{ }^{26} \mathrm{~Pb}}$} & \multirow{3}{*}{$\begin{array}{l}2 \sigma \\
{[a b s]}\end{array}$} & \multicolumn{3}{|c|}{ Apparent age [Ma] } \\
\hline & & & & & & & & & & & & ${ }^{206} \mathrm{~Pb}$ & ${ }^{207} \mathrm{~Pb}$ & ${ }^{2 \cdot 7} \mathrm{~Pb}$ \\
\hline & & & & & & & & & & & & ${ }^{238} \mathrm{U}$ & ${ }^{235} \mathrm{U}$ & ${ }^{2 \bullet 6} \mathrm{~Pb}$ \\
\hline NF-29 21 & 1 & 327.1 & 0.53 & 1.3 & 1194.1 & 0.07357 & 0.00033 & 0.5699 & 0.0043 & 0.05618 & 0.00034 & 457.6 & 457.9 & 459.4 \\
\hline NF-29 22 & 4 & 435.0 & 0.26 & 5.0 & 1613.4 & 0.07286 & 0.00036 & 0.5640 & 0.0035 & 0.05614 & 0.00022 & 453.4 & 454.1 & 457.8 \\
\hline NF-29 23 & 2 & 451.6 & 0.50 & 2.7 & 1554.2 & 0.07321 & 0.00043 & 0.5629 & 0.0040 & 0.05577 & 0.00029 & 455.5 & 453.4 & 443.2 \\
\hline NF-29 24 & 5 & 223.9 & 0.25 & 1.5 & 3545.7 & 0.07316 & 0.00029 & 0.5647 & 0.0027 & 0.05598 & 0.00014 & 455.2 & 454.6 & 451.5 \\
\hline
\end{tabular}

a Weights are known with ca. 20 to $40 \%$ uncertainty.

b Model Th/U ratio estimated from ${ }^{208} \mathrm{~Pb} /{ }^{\circ} \mathrm{Pb}$ ratio and age of the sample.

c Total common $\mathrm{Pb}$ in sample, including initial and blank $\mathrm{Pb}$.

d Measured ratio, corrected for fractionation and spike contribution.

e Corrected for spike, fractionation, blank and initial common Pb (Stacey and Kramers, 1975).

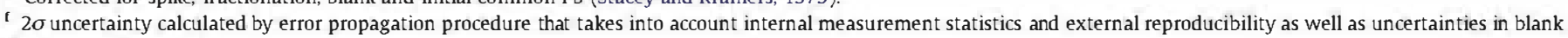
and common $\mathrm{Pb}$ correction.

drying, the zircon grains were individually weighed in a precision balance. After the size reduction induced by air-abrasion, the analyzed grains weighed between 1 and $5 \mu \mathrm{g}$ (Table 1).

A mixed ${ }^{205} \mathrm{~Pb} /{ }^{235} \mathrm{U}$ spike was added to the sample after weighing and transferring to the dissolution vessel. Zircon was dissolved in $\mathrm{HF}$ $\left(+\mathrm{HNO}_{3}\right)$ in Teflon mini-bombs at approximately $185^{\circ} \mathrm{C}$ for 5 days. Since all zircons weighed less than $5 \mu \mathrm{g}$, no chemical separation of U$\mathrm{Pb}$ was performed and the whole sample taken in $6 \mathrm{~N} \mathrm{HCl}$ was dried and loaded on out-gassed Rhenium filaments with $\mathrm{H}_{3} \mathrm{PO}_{4}$ and silica gel.

Isotopic ratios were measured on a Finnigan-MAT 262 mass spectrometer by peak jumping on a secondary electron multiplier (ion counting mode). Total procedural blanks were less than 2-5 pg Pb and 0.1-0.3 pg U. The Stacey and Kramers (1975) model was used to subtract initial common $\mathrm{Pb}$ in excess of the laboratory blank. Decay constants are those of Jaffey et al. (1971). Concordia plots and concordia age calculations were created using Isoplot 3.00 (Ludwig, 2003).

Four single grain analyses were performed on zircons from sample NF-29. All zircons were idiomorphic stubby equant prisms with a pink hue. The results of the $\mathrm{U}-\mathrm{Pb}$ analyses are given in Table 1 and are shown graphically in a concordia plot on Fig. 4. All four analyses are concordant and reproducible within error of individual measure- ments. The concordia age (Ludwig, 1998) is the most statistically robust age for this data set and yields a date of $455.2 \pm 1.8 \mathrm{Ma}$ (decay constant uncertainties included) as the best estimate for the crystallization of zircon. This age coincides within error to the base of the sixth stage of the Ordovician $(455.8 \pm 1.6 \mathrm{Ma})$, which corresponds to the middle Upper Ordovician (Katian), which is roughly equivalent to the middle Caradoc in the regional British series division (see Finney, 2005).

\section{Whole-rock geochemistry and $\mathrm{Sr}-\mathrm{Nd}$ isotopes}

Representative samples of Late Ordovician orthogneisses, metadiorite, tuffs and epiclastic ashes from the Canigó and Les Gavarres massifs were selected for whole-rock and $\mathrm{Sr}-\mathrm{Nd}$ isotopic analyses (Tables 2 and 3).

\subsection{Analytical techniques}

Major and trace elements were measured in whole-rock samples using ICP-OES (Inductively Coupled Plasma-Optical Emission Spectrometry) for major and minor elements and ICP-MS (Inductively Coupled Plasma-Mass Spectroscopy) for trace elements at the Spectrochemical Laboratory of the Centre de Recherches en Pétrographie et

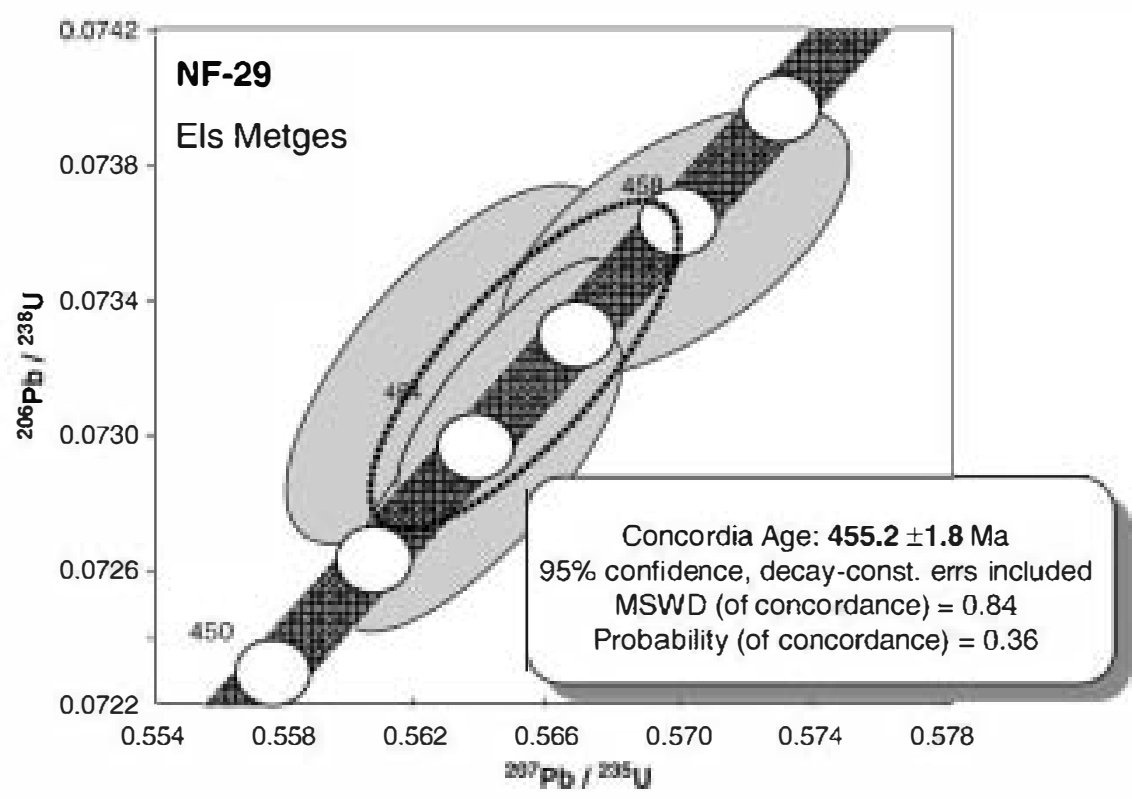

Fig. 4. U-Pb Concordia diagram for sample NF-29 (Les Gavarres massif). 


\begin{tabular}{|c|c|c|c|c|c|c|c|c|c|c|}
\hline & 100762 & 100766 & CG-07-03 & $\mathrm{C} 96767 \mathrm{Q} 2 \mathrm{~b}$ & 100786 & CG-07-05 & 100768 & C96940F & 770288 & CG-07-02 \\
\hline & $\begin{array}{l}\text { Felsic } \\
\text { orthogneiss }\end{array}$ & $\begin{array}{l}\text { Bt } \\
\text { orthogneiss }\end{array}$ & $\begin{array}{l}\text { Bt } \\
\text { orthogneiss }\end{array}$ & $\begin{array}{l}\text { Bt } \\
\text { orthogneiss }\end{array}$ & $\begin{array}{l}\text { Bt } \\
\text { orthogneiss }\end{array}$ & $\begin{array}{l}\text { Amp } \\
\text { orthogneiss }\end{array}$ & $\begin{array}{l}\text { Amp } \\
\text { orthogneiss }\end{array}$ & $\begin{array}{l}\text { Amp } \\
\text { orthogneiss }\end{array}$ & $\begin{array}{l}\text { Amp } \\
\text { orthogneiss }\end{array}$ & $\begin{array}{l}\text { Marialles } \\
\text { diorite }\end{array}$ \\
\hline $\mathrm{SiO}_{2}$ & 74.55 & 75.02 & 74.77 & 73.62 & 76.03 & 74.16 & 71.87 & 75.13 & 56.47 & 50.25 \\
\hline $\mathrm{TiO}_{2}$ & 0.2 & 0.21 & 0.21 & 0.2 & 0.13 & 0.22 & 0.62 & 0.29 & 1.73 & 1.33 \\
\hline $\mathrm{Al}_{2} \mathrm{O}_{3}$ & 13.03 & 13.04 & 12.54 & 12.49 & 12.5 & 13.14 & 12.45 & 11.57 & 12.17 & 15.50 \\
\hline $\mathrm{Fe}_{2} \mathrm{O}_{3}$ & 2.39 & 2.32 & 2.37 & 2.75 & 1.63 & 1.99 & 4.96 & 3.28 & 13.58 & 9.66 \\
\hline $\mathrm{MnO}$ & $<\mathrm{DL}$ & $<\mathrm{DL}$ & 0.03 & 0.02 & 0.01 & 0.04 & 0.03 & 0.03 & 0.24 & 0.15 \\
\hline $\mathrm{MgO}$ & 0.32 & 0.32 & 0.64 & 0.32 & 0.12 & 0.38 & 0.57 & 0.12 & 1.87 & 7.28 \\
\hline $\mathrm{CaO}$ & 0.35 & 0.51 & 0.23 & 0.4 & 0.65 & 0.5 & 1.7 & 0.86 & 5.9 & 8.70 \\
\hline $\mathrm{Na}_{2} \mathrm{O}$ & 2.67 & 3.34 & 2.84 & 2.88 & 1.82 & 4.01 & 4.02 & 2.94 & 3.15 & 2.62 \\
\hline $\mathrm{K}_{2} \mathrm{O}$ & 5.77 & 4.49 & 4.66 & 5.8 & 6.3 & 4.11 & 3.24 & 4.27 & 2.91 & 1.28 \\
\hline $\mathrm{P}_{2} \mathrm{O}_{5}$ & 0.03 & 0.04 & 0.02 & 0.14 & 0.06 & 0.02 & 0.12 & 0.03 & 0.72 & 0.24 \\
\hline $\mathrm{H}_{2} \mathrm{O}$ & 0.59 & 0.65 & 0.97 & 0.77 & 0.62 & 0.49 & 0.37 & 0.91 & 0.96 & 1.56 \\
\hline Total & 99.91 & 99.95 & 99.28 & 99.39 & 99.87 & 99.06 & 99.95 & 99.42 & 99.70 & 98.58 \\
\hline $\mathrm{Ba}$ & 953 & 1082 & 1025 & 942 & 464 & 714 & 780 & 1087 & 755 & 180 \\
\hline $\mathrm{Be}$ & 3.5 & 3.5 & 3.0 & 1.3 & 2.9 & 2.3 & 3.7 & 3.6 & 3.5 & $<\mathrm{DL}$ \\
\hline Co & 1.2 & 1.7 & 1.4 & 1.2 & 0.9 & 0.7 & 4.0 & 0.6 & 1.2 & 37.6 \\
\hline $\mathrm{Cr}$ & 90 & 202 & 6 & - & 160 & 7 & 1.12 & $<\mathrm{DL}$ & 8 & 260 \\
\hline $\mathrm{Cu}$ & 3 & 5 & 7 & 10 & 21 & $<\mathrm{DL}$ & 24 & 42 & 50 & 37 \\
\hline $\mathrm{Ga}$ & 22 & 23 & 20 & 19 & 22 & 23 & 22 & 23 & 24 & 19 \\
\hline Hf & 11 & 10 & 10 & 9 & 4 & 11 & 12 & 14 & - & 4 \\
\hline $\mathrm{Nb}$ & 15 & 14 & 13 & 12 & 12 & 14 & 19 & 21 & 16 & 10 \\
\hline $\mathrm{Ni}$ & 4 & 8 & 4 & 5 & 7 & 4 & 5 & $<\mathrm{DL}$ & 9 & 103 \\
\hline $\mathrm{Rb}$ & 162 & 138 & 112 & 228 & 242 & 109 & 110 & 115 & 84 & 61 \\
\hline $\mathrm{Sc}$ & & $=$ & + & 5 & $=$ & - & + & $=$ & 34 & \\
\hline $\mathrm{Sr}$ & 45 & 55 & 52 & 39 & 36 & 42 & 155 & 174 & 180 & 229 \\
\hline Ta & 1.4 & 1.3 & 1.3 & 1.2 & 1.4 & 1.3 & 1.6 & 1.7 & 1.6 & 0.8 \\
\hline Th & 23 & 22 & 20 & 17 & 16 & 23 & 17 & 17 & 16 & 4 \\
\hline $\mathrm{U}$ & 3 & 4 & 5 & 4 & 8 & 6 & 4 & 4 & 4 & 1 \\
\hline V & 3 & 6 & 2 & 4 & 6 & 3 & 8 & $<\mathrm{DL}$ & 49 & 186 \\
\hline Y & 60 & 64 & 65 & 50 & 59 & 71 & 68 & 86 & 68 & 27 \\
\hline $\mathrm{Zn}$ & 21 & 20 & 15 & 28 & 230 & 19 & 29 & 34 & 122 & 132 \\
\hline $\mathrm{Zr}$ & 322 & 325 & 327 & 321 & 126 & 338 & 443 & 605 & 267 & 137 \\
\hline la & 52 & 43 & 35 & 52 & 22 & 54 & 42 & 41 & 33 & 16 \\
\hline $\mathrm{Ce}$ & 107 & 92 & 73 & 112 & 51 & 111 & 97 & 92 & 83 & 34 \\
\hline Pr & 12.40 & 11.20 & 8.89 & - & 6.09 & 13.39 & 12.10 & 11.56 & - & 4.37 \\
\hline Nd & 45 & 44 & 34 & 47 & 22 & 50 & 48 & 47 & 43 & 18 \\
\hline $\mathrm{Sm}$ & 10.60 & 10.30 & 8.36 & 10.45 & 6.41 & 11.29 & 11.30 & 11.57 & 11.46 & 4.51 \\
\hline $\mathrm{Eu}$ & 1.04 & 1.11 & 0.71 & 0.85 & 0.52 & 0.95 & 2.22 & 1.90 & 2.92 & 1.37 \\
\hline $\mathrm{Gd}$ & 9.44 & 9.32 & 9.00 & 9.40 & 6.07 & 11.02 & 10.60 & 12.18 & 11.94 & 4.51 \\
\hline $\mathrm{Tb}$ & 1.55 & 1.59 & 1.60 & $=$ & 1.28 & 1.90 & 1.73 & 2.17 & $=$ & 0.77 \\
\hline Dy & 10.10 & 10.20 & 10.39 & 9.00 & 8.84 & 11.82 & 11.20 & 13.77 & 11.83 & 4.60 \\
\hline Ho & 2.18 & 2.24 & 2.18 & - & 1.91 & 2.36 & 2.42 & 2.83 & - & 0.94 \\
\hline Er & 5.89 & 6.07 & 6.47 & 5.13 & 5.47 & 6.89 & 6.26 & 8.29 & 6.34 & 2.63 \\
\hline $\mathrm{Tm}$ & 0.90 & 1.03 & 1.02 & - & 0.87 & 1.05 & 1.05 & 1.28 & - & 0.38 \\
\hline $\mathrm{Yb}$ & 6.37 & 6.40 & 7.04 & 5.09 & 6.04 & 6.90 & 7.01 & 8.56 & 6.06 & 2.52 \\
\hline Lu & 0.94 & 0.95 & 1.09 & 0.63 & 0.81 & 1.04 & 0.99 & 1.29 & 0.77 & 0.40 \\
\hline
\end{tabular}

DL, detection limit.

a Sample dated in Casas et al. (2010-this issue).

Géochimie (Centre National de la Recherche Scientifique) in Nancy, France. Whole-rock samples were prepared by fusion with $\mathrm{LiBO}_{2}$ and $\mathrm{HNO}_{3}$ dissolution. Precision and accuracy were both found to be better than $1 \%$ (mean $0.5 \%$ ) for major-minor elements, $5 \%$ for $\mathrm{Cr}, \mathrm{U}, \mathrm{V}$ and $\mathrm{Zn}$, and $10 \%$ for $\mathrm{Ni}$ and $\mathrm{Cu}$ as corroborated by international standards and analysis of replicate samples (Carignan et al., 2001).

$\mathrm{Sr}-\mathrm{Nd}$ analyses were carried out at the Centro de Geocronología y Geoquímica Isotópica (Universidad Complutense) in Madrid using IDTIMS. Whole-rock samples were dissolved in ultra-pure reagents and the isotopes were subsequently isolated by exchange chromatography. The analyses were performed with a Sector 54 VG-Micromass Multicollector Spectrometer. Measured isotopic ratios were normalized to ${ }^{146} \mathrm{Nd} /{ }^{144} \mathrm{Nd}=0.7219$ in order to correct mass fractionation. Replicate analyses of the NBS-987 Sr-isotope standard yielded an average ${ }^{87} \mathrm{Sr} /{ }^{86} \mathrm{Sr}$ ratio of $0.710252 \pm 0.00002(n=435)$, whereas 195 analyses of the Johnson and Matthey Nd-standard over 1 year yielded a mean ${ }^{143} \mathrm{Nd} /{ }^{144} \mathrm{Nd}$ ratio of $0.511837 \pm 0.00004$. The decay constants used in the calculations are the values recommended by the IUGS Subcommission for Geochronology (Steiger and Jäger, 1977). Analyt- ical uncertainties are $0.01 \%$ for ${ }^{87} \mathrm{Sr} /{ }^{86} \mathrm{Sr}$ ratios, $0.006 \%$ for ${ }^{143} \mathrm{Nd} /{ }^{144} \mathrm{Nd}$ ratios, $1.0 \%$ for ${ }^{87} \mathrm{Rb} /{ }^{86} \mathrm{Rb}$ ratios, and $0.1 \%$ for ${ }^{147} \mathrm{Sm} /{ }^{144} \mathrm{Nd}$ ratios. Epsilon-Nd $(\varepsilon \mathrm{Nd})$ values (Jacobsen and Wasseburg, 1980) were calculated relative to a chondrite present-day ${ }^{143} \mathrm{Nd} /{ }^{144} \mathrm{Nd}$ value of 0.51262 and ${ }^{147} \mathrm{Sm} /{ }^{144} \mathrm{Nd}$ ratio of 0.1967 .

\subsection{Whole-rock geochemistry}

Twenty-two samples were collected for whole-rock analysis (Table 2), eleven from each of the two massifs (Canigó and Les Gavarres). Samples from the Canigó massif show variable silica content (see Table 1 and Supplementary Fig. ES-1). The Casemí and Cadi gneisses show uniformly high silica content (70-76 wt.\%), the biotitic gneiss and the felsic gneiss being richer in $\mathrm{SiO}_{2} . \mathrm{Fe}_{\text {total }}, \mathrm{MgO}$ and $\mathrm{CaO}$ concentrations are low (CaO, 0.2-1.7 wt.\%; $\mathrm{Fe}_{\text {total }}, 1.6-5 \mathrm{wt} . \%$; MgO 0.1-1.9 wt.\%) and uniform, although they tend to be higher in the amphibole gneiss than in the felsic gneiss. The Marialles metadiorite show a lower silica content (50\%) and higher $\mathrm{Fe}_{\text {total, }}$ $\mathrm{MgO}$ and $\mathrm{CaO}$ values than those of Casemi gneiss. $\mathrm{Al}_{2} \mathrm{O}_{3}$ content varies 


\begin{tabular}{|c|c|c|c|c|c|c|c|c|c|c|c|}
\hline CG-07-01 & NF-29 $9^{a}$ & NF-30 & NF-32 & NF-39 & NF-50 & NF-63 & NF-64 & NF-8 & NF-31 & NF-44 & NF-52 \\
\hline $\begin{array}{l}\text { Cadi } \\
\text { orthogneiss }\end{array}$ & $\begin{array}{l}\text { Volcanic } \\
\text { tuff }\end{array}$ & $\begin{array}{l}\text { Volcanic } \\
\text { tuff }\end{array}$ & $\begin{array}{l}\text { Volcanic } \\
\text { tuff }\end{array}$ & $\begin{array}{l}\text { Volcanic } \\
\text { tuff }\end{array}$ & $\begin{array}{l}\text { Volcanic } \\
\text { tuff }\end{array}$ & $\begin{array}{l}\text { Volcanic } \\
\text { tuff }\end{array}$ & $\begin{array}{l}\text { Epiclastic } \\
\text { ash }\end{array}$ & $\begin{array}{l}\text { Epiclastic } \\
\text { ash }\end{array}$ & $\begin{array}{l}\text { Epiclastic } \\
\text { ash }\end{array}$ & $\begin{array}{l}\text { Epiclastic } \\
\text { ash }\end{array}$ & $\begin{array}{l}\text { Epiclastic } \\
\text { ash }\end{array}$ \\
\hline 69.38 & 69.05 & 68.61 & 68.53 & 65.81 & 70.89 & 62.98 & 77.80 & 84.24 & 77.01 & 72.34 & 86.06 \\
\hline 0.52 & 0.61 & 0.6 & 0.58 & 1.58 & 0.59 & 0.69 & 0.44 & 0.36 & 0.16 & 0.51 & 0.26 \\
\hline 14.12 & 14.68 & 14.79 & 14.46 & 17.04 & 15.1 & 15.28 & 12.48 & 9. 14 & 12.64 & 14.74 & 8.56 \\
\hline 3.74 & 4.97 & 4.77 & 4.85 & 3.9 & 3.81 & 9.08 & 1.67 & 1.59 & 1.85 & 3.66 & 0.91 \\
\hline 0.08 & 0.04 & 0.06 & 0.06 & 0.04 & 0.06 & 0.07 & 0.02 & 0.01 & 0.01 & 0.01 & 0 \\
\hline 0.96 & 0.81 & 0.78 & 0.7 & 1.23 & 0.58 & 2.43 & 0.38 & 0.24 & 0.37 & 0.67 & 0.19 \\
\hline 1.35 & 0.2 & 0.95 & 1.8 & 0.32 & 0.22 & 0.69 & 0.07 & 0.03 & 0.40 & 0.03 & $<\mathrm{DL}$ \\
\hline 3.03 & 2.29 & 2.99 & 2.74 & 4.09 & 2.05 & 2.75 & 1.82 & 0.05 & 5.13 & 0.25 & 0.1 \\
\hline 4.05 & 3.31 & 4.07 & 4.33 & 2.11 & 3.04 & 2.25 & 2.77 & 2.65 & 1.28 & 3.32 & 2.46 \\
\hline 0.19 & 0.17 & 0.17 & 0.17 & 0.22 & 0.16 & 0.16 & 0.05 & 0.03 & 0.05 & 0.03 & 0.02 \\
\hline 1.20 & 2.95 & 2.32 & 0.97 & 2.58 & 3.03 & 3.40 & 1.75 & 1.55 & 1.07 & 3.31 & 1.67 \\
\hline 98.62 & 99.06 & 100.11 & 99.2 & 98.92 & 99.52 & 99.77 & 99.24 & 99.88 & 99.97 & 98.86 & 100.23 \\
\hline 764 & 605 & 1060 & 1160 & 1110 & 716 & 452 & 609 & 446 & 499 & 397 & 382 \\
\hline 2.2 & $=$ & $=$ & * & - & $*$ & $*$ & + & t & s & $*$ & - \\
\hline 5.5 & 5.2 & 8.1 & 4.5 & 9.3 & 4.4 & 5.0 & 4.0 & 1.9 & 2.4 & 2.9 & 1.7 \\
\hline 37 & $<\mathrm{DL}$ & 101 & 92 & 79 & 30 & 226 & 498 & 471 & 226 & 79 & 177 \\
\hline 11 & 13.0 & 16.4 & 14.6 & $<\mathrm{DL}$ & 12.4 & 19.4 & 23.7 & 16.3 & $<\mathrm{DL}$ & $<\mathrm{DL}$ & $<\mathrm{DL}$ \\
\hline 20 & 20.6 & 20.5 & 19.8 & 23.6 & 22.6 & 21.8 & 14.6 & 12.1 & 13.8 & 18.6 & 10.7 \\
\hline 6 & 8.5 & 7.9 & 7.7 & 10.2 & 8.3 & 7.6 & 5.0 & 3.1 & 2.2 & 4.2 & 3.1 \\
\hline 13 & 14.7 & 14.8 & 14.1 & 25.3 & 16.5 & 16.1 & 10.4 & 8.1 & 5.2 & 12.8 & 6.6 \\
\hline 14 & $<\mathrm{DL}$ & $<\mathrm{DL}$ & $<\mathrm{DL}$ & $<\mathrm{DL}$ & $<\mathrm{DL}$ & 20.2 & 29.2 & 27.4 & $<\mathrm{DL}$ & $<\mathrm{DL}$ & $<\mathrm{DL}$ \\
\hline 159 & 116 & 137 & 130 & 73 & 124 & 107 & 97 & 108 & 47 & 106 & 79 \\
\hline+ & $*$ & - & - & + & + & $*$ & $=$ & it & $=$ & 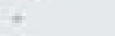 & $=$ \\
\hline 107 & 73 & 100 & 128 & 218 & 82 & 84 & 38 & 11 & 160 & 21 & 11 \\
\hline 1.2 & 1.1 & 1.1 & 1.3 & 1.6 & 1.1 & 1.2 & 0.7 & 0.4 & 0.4 & 0.9 & 0.4 \\
\hline 17 & 14.9 & 15.6 & 14.6 & 13.5 & 15.3 & 14.7 & 6.3 & 4.8 & 4.5 & 10.1 & 3.7 \\
\hline 3 & 3.6 & 3.7 & 3.1 & 3.1 & 4.1 & 6.0 & 2.1 & 0.7 & 1.3 & 2.6 & 0.9 \\
\hline 40 & 23.9 & 26.6 & 23.2 & 106.8 & 23.1 & 27.8 & 18.7 & 14.9 & 10.8 & 52.5 & 15.7 \\
\hline 41 & 48.7 & 80.0 & 44.3 & 42.8 & 48.0 & 46.6 & 14.1 & 16.6 & 11.5 & 30.4 & 10.0 \\
\hline 50 & 81 & 99 & 87 & 118 & 118 & 133 & bdl & 34 & 36 & 126 & $<\mathrm{DL}$ \\
\hline 202 & 320 & 299 & 303 & 405 & 322 & 291 & 190 & 118 & 71 & 143 & 126 \\
\hline 38 & 39 & 115 & 37 & 50 & 46 & 40 & 22 & 22 & 14 & 35 & 20 \\
\hline 76 & 78 & 109 & 75 & 102 & 94 & 80 & 41 & 45 & 22 & 77 & 38 \\
\hline 8.89 & 9.09 & 21.89 & 8.72 & 11.58 & 10.76 & 9. 31 & 4.53 & 5.08 & 2.80 & 8.41 & 4.13 \\
\hline 34 & 37 & 81 & 34 & 46 & 42 & 37 & 17 & 20 & 11 & 33 & 15 \\
\hline 7.30 & 8.67 & 17.24 & 7.75 & 10.08 & 9.18 & 8.57 & 3.40 & 4.56 & 2.30 & 6.83 & 2.95 \\
\hline 1.08 & 1.35 & 2.55 & 1.17 & 1.41 & 1.54 & 1.34 & 0.99 & 0.93 & 0.76 & 1.37 & 0.91 \\
\hline 6.56 & 8.51 & 17.75 & 7.71 & 9.32 & 8.88 & 8.22 & 3.00 & 4.07 & 2.22 & 5.66 & 2.40 \\
\hline 1.10 & 1.53 & 2.91 & 1.33 & 1.51 & 1.53 & 1.47 & 0.48 & 0.62 & 0.37 & 0.95 & 0.36 \\
\hline 6.72 & 8.57 & 15.11 & 7.49 & 8.07 & 8.36 & 8.14 & 2.61 & 3.07 & 1.99 & 5.33 & 1.85 \\
\hline 1.34 & 1.61 & 2.76 & 1.45 & 1.52 & 1.60 & 1.54 & 0.52 & 0.54 & 0.39 & 1.03 & 0.33 \\
\hline 3.81 & 5.13 & 8.24 & 4.65 & 4.75 & 5.15 & 4.80 & 1.62 & 1.64 & 1.24 & 3.26 & 1.03 \\
\hline 0.56 & 0.76 & 1.14 & 0.70 & 0.71 & 0.76 & 0.69 & 0.23 & 0.23 & 0.18 & 0.47 & 0.15 \\
\hline 3.60 & 4.56 & 6.63 & 4.26 & 4.53 & 4.53 & 4.08 & 1.47 & 1.41 & 1.12 & 2.88 & 0.96 \\
\hline 0.53 & 0.68 & 1.00 & 0.64 & 0.68 & 0.69 & 0.59 & 0.23 & 0.21 & 0.16 & 0.42 & 0.15 \\
\hline
\end{tabular}

between 11.6 and $15.5 \mathrm{wt} . \%$, the highest value being those of the metadiorite. $\mathrm{Na}_{2} \mathrm{O}$ and $\mathrm{K}_{2} \mathrm{O}$ values are high in all analyzed orthogneiss samples $\left(\mathrm{Na}_{2} \mathrm{O}, 1.8-4 \mathrm{wt} . \% ; \mathrm{K}_{2} \mathrm{O}, 2.9-6.3 \mathrm{wt} \%\right)$ and show a wide scatter. Samples from Els Metges tuffs (Les Gavarres massif) show variable silica content, the quartz-feldspatic tuff containing 63-71 wt.\% $\mathrm{SiO}_{2}$, whereas the epiclastic ash is more silica rich, with $72-86 \mathrm{wt} . \% \mathrm{SiO}_{2}$. The epiclastic ash also has lower concentrations of $\mathrm{Al}_{2} \mathrm{O}_{3}, \mathrm{Fe}_{\text {total, }} \mathrm{MgO}$ and $\mathrm{CaO}$ than those of the tuff. These elements shownegative trends in all the samples, whereas the contents of $\mathrm{Na}_{2} \mathrm{O}$ and $\mathrm{K}_{2} \mathrm{O}$ vary considerably with no defined trend.

In summary, as all samples have been subjected to variable degrees of metamorphism, the mobile elements ( $\mathrm{CaO}, \mathrm{Na}_{2} \mathrm{O}, \mathrm{K}_{2} \mathrm{O}$ and $\mathrm{Rb}$ ) tend to show poor correlations, whereas the most immobile elements $\left(\mathrm{Al}_{2} \mathrm{O}_{3}, \mathrm{Fe}_{\text {total }}\right.$ and $\left.\mathrm{MgO}\right)$ show good negative trends. Consequently, the classification diagrams used are based on immobile elements (see below, Fig. 5).

Trace and rare earth element (REE) contents in the Canigó massif samples are similar to, or higher than, those in the Les Gavarres massif samples (Table 2). In the Canigó samples, the trace elements show no clear correlation (see Supplementary Fig. ES-2). Samples from Les Gavarres, on the other hand, plot along trends with negative slopes, $\mathrm{Rb}$ displaying the most scattered values.

On the $\mathrm{Zr} / \mathrm{TiO}_{2}$ versus $\mathrm{Nb} / \mathrm{Y}$ diagram (Winchester and Floyd, 1977; Fig. 5a), felsic rocks from both massifs (tuff and epiclastic ash, and amphibole or biotite orthogneiss) plot in the rhyodacite and rhyolite fields, with no apparent compositional differences between the samples. The Marialles metadiorite plots in the andesite field. In the Th versus Co diagram (Hastie et al., 2007; Fig. 5b), all samples plot in the high-K calc-alkaline field, although some volcanic tuffs fall within the calc-alkaline area.

Mantle-normalized trace element plots (normalization values after Wood et al., 1979; Fig. 6a, b) display similar patterns for all rocks irrespective of their location. These patterns are characterized by a smooth negative slope produced by a subtle enrichment in the more incompatible elements. All samples exhibit negative $\mathrm{Sr}, \mathrm{P}, \mathrm{Ti}$ and Ta-Nb anomalies. In Les Gavarres massif, the contents of all elements are lower in the epiclastic ashes than in the volcanic tuffs. For the Canigó massif, the Marialles metadiorite shows lower contents in 
Table 3

Isotopic Sr and Nd ratios for Casemi orthogneisses and Els Metges volcanic tuffs from Canigó and Les Gavarres massifs (Eastern Pyrenees and Catalonian coastal range).

\begin{tabular}{|c|c|c|c|c|c|c|c|c|c|c|c|}
\hline & & $\mathrm{Sm} / \mathrm{Nd}$ & $\mathrm{Rb} / \mathrm{Sr}$ & $\left({ }^{147} \mathrm{Sm} /{ }^{144} \mathrm{Nd}\right)$ & $\left({ }^{7} \mathrm{Sr} /{ }^{26} \mathrm{Sr}\right)$ & $\left({ }^{87} \mathrm{Sr} /{ }^{6} \mathrm{Sr}\right)_{455}$ & $\left({ }^{143} \mathrm{Nd} /{ }^{144} \mathrm{Nd}\right) 0$ & $\left({ }^{143} \mathrm{Nd} /{ }^{144} \mathrm{Nd}\right)_{455}$ & $\varepsilon \mathrm{Nd}$ & $T_{\bullet M}(\mathrm{Ga})$ & Age (Ma) \\
\hline \multicolumn{12}{|c|}{ Les Gavarres massif } \\
\hline$N F-2 s^{a}$ & Volcanic tuff & 0.23 & 1.59 & 0.1416 & 0.733067 & 0.703181 & 0.512227 & 0.511805 & -4.8 & 1.6 & 455.2 \\
\hline NF-32 & Volcanic tuff & 0.23 & 1.02 & 0.1374 & 0.726113 & 0.707025 & 0.512211 & 0.511802 & -4.9 & 1.6 & \\
\hline NF-63 & Volcanic tuff & 0.23 & 1.27 & 0.1404 & 0.729263 & 0.705315 & 0.512205 & 0.511787 & -5.2 & 1.7 & \\
\hline \multicolumn{12}{|c|}{ Canigô massif } \\
\hline CG-07-05 & Bt orthogneiss & 0.22 & 2.58 & 0.1356 & 0.745438 & 0.696910 & 0.512393 & 0.511989 & -1.2 & 1.3 & 451.6 \\
\hline CG-07-03 ${ }^{a}$ & Bt orthogneiss & 0.24 & 2.15 & 0.1469 & 0.742716 & 0.702258 & 0.512401 & 0.511963 & -1.7 & 1.4 & 445.9 \\
\hline 100786 & Bt orthogneiss & 0.29 & 6.67 & 0.1730 & 0.817270 & 0.690857 & 0.512390 & 0.511874 & -3.5 & 2.2 & \\
\hline 100766 & Bt orthogneiss & 0.24 & 2.52 & 0.1445 & 0.754248 & 0.706702 & 0.512409 & 0.511978 & -1.4 & 1.4 & \\
\hline C96767aQ2 & Bt orthogneiss & 0.22 & 5.85 & 0.1346 & 0.770513 & 0.660161 & 0.512300 & 0.511899 & -3.0 & 1.4 & \\
\hline C-96940F & Amp orthogneiss & 0.25 & 0.66 & 0.1486 & 0.720939 & 0.708524 & 0.512383 & 0.511940 & -2.2 & 1.5 & \\
\hline C-770288 & Amp orthogneiss & 0.27 & 0.47 & 0.1616 & 0.718292 & 0.709528 & 0.512328 & 0.511846 & -4.0 & 2.0 & \\
\hline 100768 & Amp orthogneiss & 0.23 & 0.71 & 0.1417 & 0.720992 & 0.707661 & 0.512355 & 0.511933 & -2.3 & 1.4 & \\
\hline CG-07-02 & Marialles diorite & 0.24 & 0.27 & 0.1474 & 0.736385 & 0.731345 & 0.512461 & 0.512022 & -0.6 & 1.3 & 453.0 \\
\hline CG-07-01 & Cadi orthogneiss & 0.22 & 1.48 & 0.1305 & 0.736385 & 0.708542 & 0.512227 & 0.511838 & -4.2 & 1.5 & 456.1 \\
\hline
\end{tabular}

a Age Ma from Casas et al. (2010-this issue) and in this work

incompatible elements than the orthogneisses although the same anomalies are present. The enrichment in incompatible elements, which is more pronounced in the volcanic patterns, suggests crustal involvement in magma processes. The negative $\mathrm{Ta}-\mathrm{Nb}$ anomaly is related to a subduction component. Additionally, negative $\mathrm{Sr}, \mathrm{P}$ and $\mathrm{Ti}$ anomalies are characteristic of calc-alkaline suites from mature continental volcanic arcs (Brown et al., 1984).

The chondrite-normalized REE plot (normalization values after Evensen et al., 1978) for all samples reveals strong similarities. In the Les Gavarres massif, REE patterns show a higher slope in the volcanic
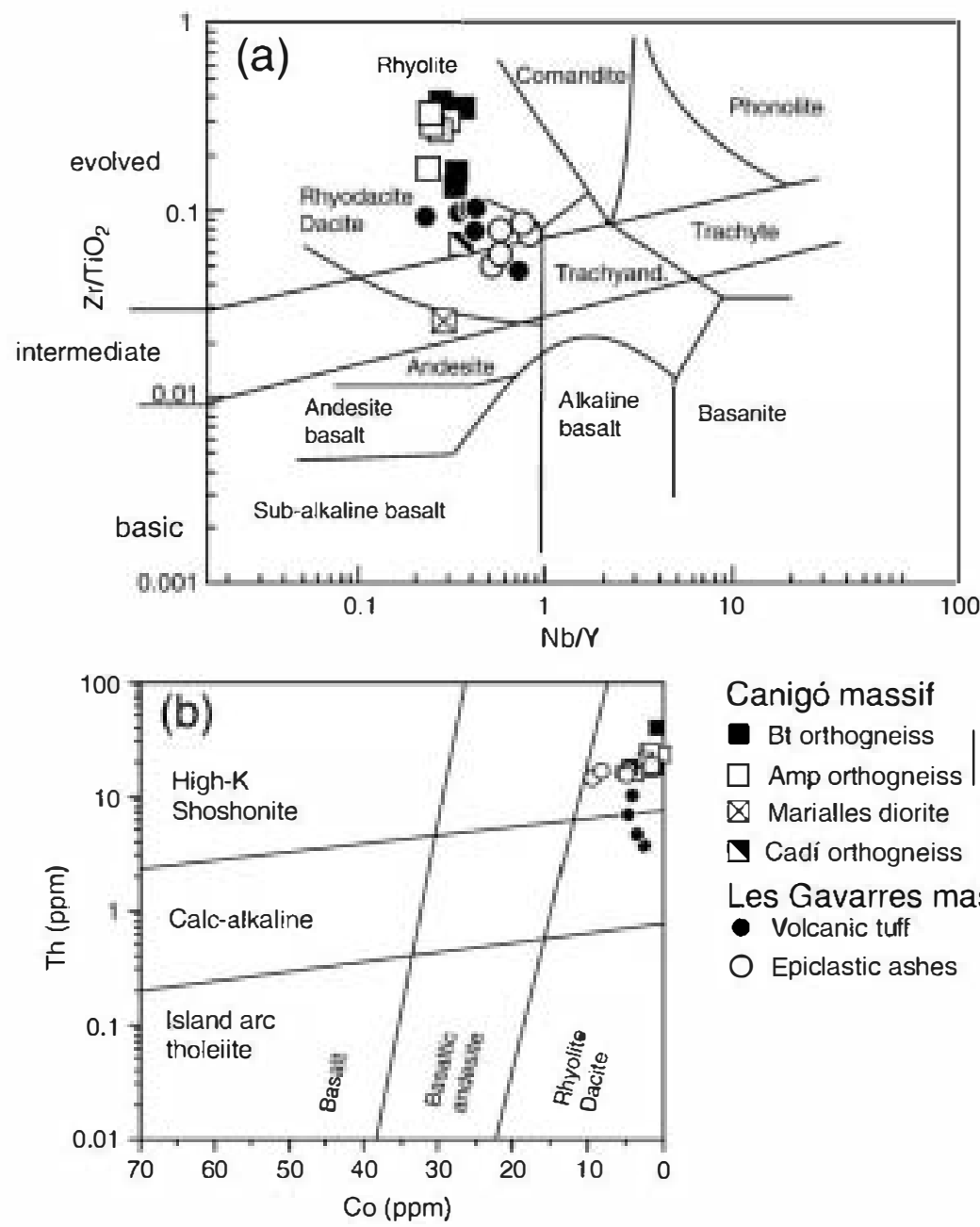

Canigó massif

Bt orthogneiss

$\square$ Amp orthogneiss $\mid \begin{gathered}0 \\ 0 \\ 0 \\ 0\end{gathered}$

$\triangle$ Marialles diorite

$\Delta$ Cadi orthogneiss

Les Gavarres massif

- Volcanic tuff

Epiclastic ashes

Fig. 5. Classification diagrams for igneous rocks based on immobile elements. (a) $\mathrm{Zr} / \mathrm{IiO}_{2}$ versus $\mathrm{Nb} / \mathrm{Y}$ diagram (Winchester and Floyd, 1977 ), and (b) Th versus $\mathrm{Co}$ diagram (Hastie et al., 2007) used to determine the alkaline index. See text for explanation. 

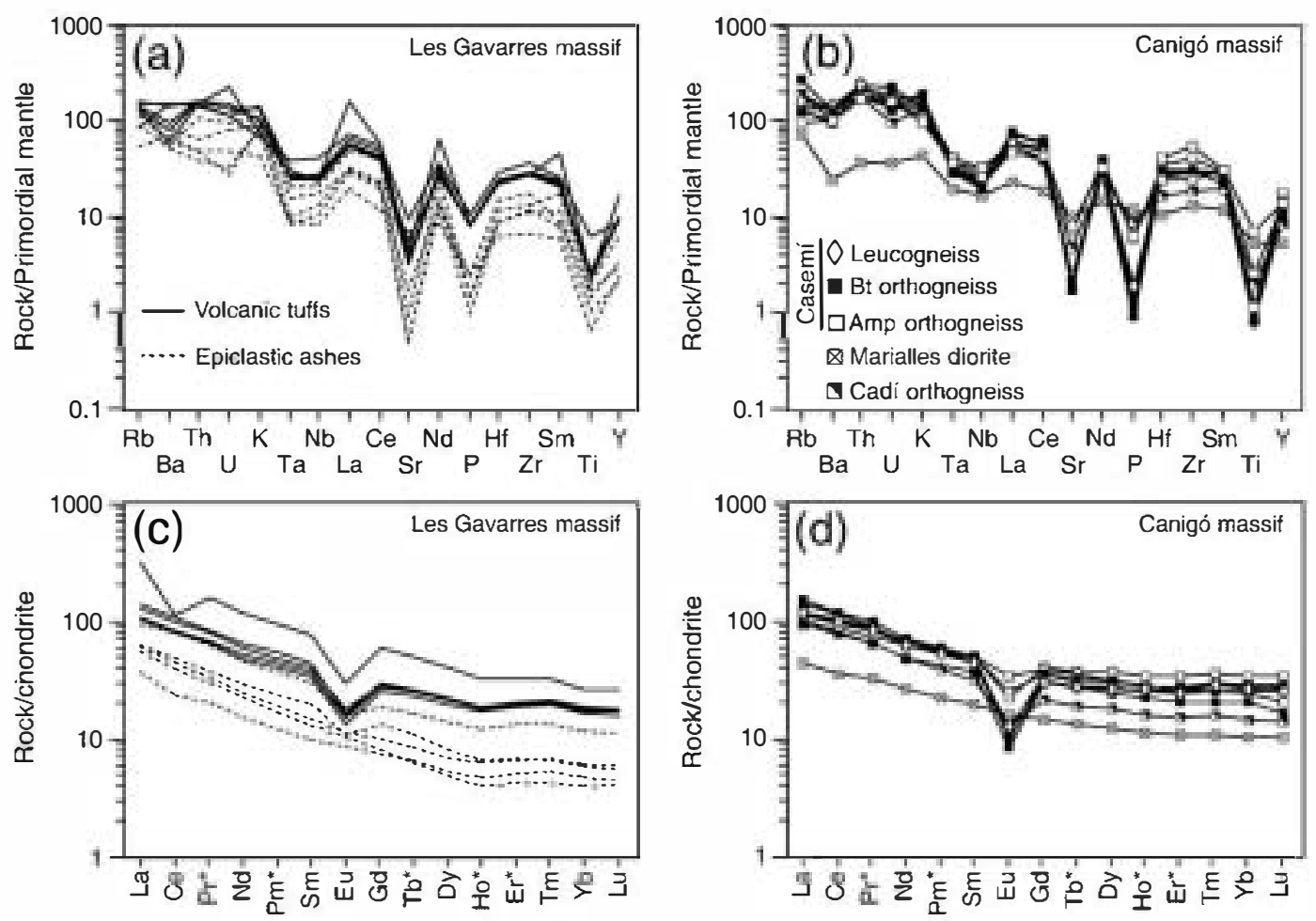

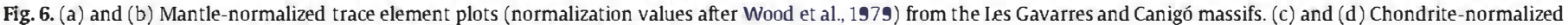
REE plots (normalization values after Evensen et aI., 1978) for the Ies Gavarres and Canigó and massifs.

tuff $\left(\mathrm{La}_{\mathrm{N}} / \mathrm{Lu}_{\mathrm{N}}=5.9-7.6\right)$ than in the epiclastic ash $\left(\mathrm{La}_{\mathrm{N}} / \mathrm{Lu}_{\mathrm{N}}=8.5-\right.$ 13.7) (Fig. 6c), and a negative Eu anomaly ( $\mathrm{Eu} / \mathrm{Eu}^{*}=0.44-0.52$, in the volcanic tuff; $\mathrm{Eu} / \mathrm{Eu}^{*}=0.20-0.30$, in the epiclastic ash). The negative Eu anomaly indicates crystallization from evolved felsic magmas with plagioclase fractionation. In the Canigo samples, the chondritenormalized REE plot (Fig. 6d) shows a moderate slope ( $\mathrm{La}_{\mathrm{N}} /$ $\mathrm{Lu}_{\mathrm{N}}=4-7$ ) with a negative $\mathrm{Eu}$ anomaly $\left(\mathrm{Eu} / \mathrm{Eu}^{*}=0.25-0.76\right)$. The pattern for the Marialles metadiorite displays a similar slope ( $\mathrm{La}_{\mathrm{N}}$ ) $\mathrm{Lu}_{\mathrm{N}}=4.23$ ), although its REE content is lower and the Eu negative anomaly is less pronounced $\left(\mathrm{Eu} / \mathrm{Eu}^{*}=0.93\right)$. All these REE patterns are comparable to those found in calc-alkaline magmas from active margin environments or from evolved crustal melts.

To gain further insight into the possible tectonic setting for these rocks, the relation between characteristically immobile elements $\mathrm{Nb}$ and Y (Pearce et al., 1984) has been plotted (Fig. 7). In this diagram, all

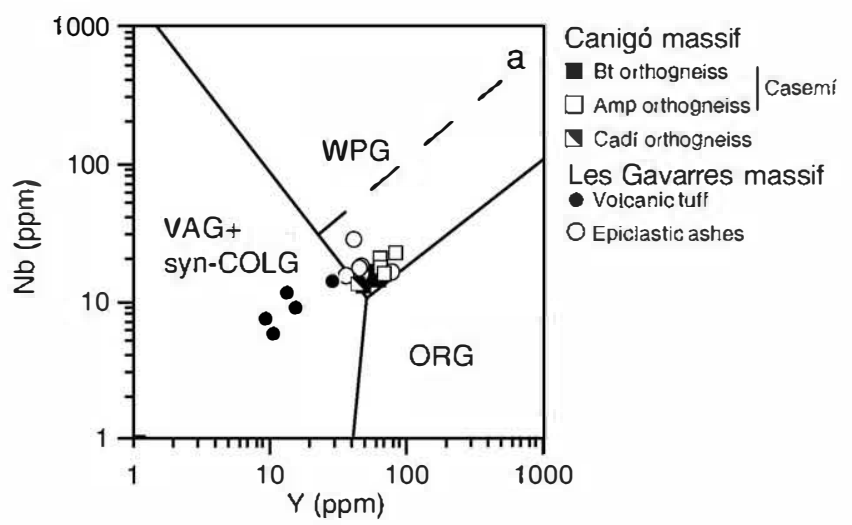

Fig. 7. Nb versus Y tectonic setting discrimination diagram for felsic rocks (Pearce et al., 1984). samples fall into the area of anomalous rift, except for the volcaniclastic rocks, which are displaced into the arc setting. However, as Twist and Harmer (1987) point out, the trace element geochemistry in juvenile rocks contaminated by crustal rocks may preserve the tectonic setting signature of the crustal component.

\section{3. $\mathrm{Sr}-\mathrm{Nd}$ isotopes}

Thirteen samples were selected for $\mathrm{Sr}$ and $\mathrm{Nd}$ isotopic analysis, ten from the Canigó massif and three from the Les Gavarres massif (Table 3). Initial ${ }^{87} \mathrm{Sr} /{ }^{86} \mathrm{Sr}$ values in some of the samples are very low $(<0.702)$, suggesting that this isotopic system was disturbed, ruling out its use. Some samples of volcanic tuff and felsic orthogneiss have plausible initial isotopic ratios (between 0.7023 and 0.7095 ), but these results were rejected owing to the sensitivity of the $\mathrm{Rb}-\mathrm{Sr}$ system to disturbance.

In contrast, the initial ${ }^{143} \mathrm{Nd} /{ }^{144} \mathrm{Nd}$ ratios are more uniform. In the Casemi orthogneiss, this ratio varies between 0.5118 and 0.5119 , and is 0.5120 in the Marialles metadiorite. The Cadi orthogneiss shows a $\mathrm{Nd}$ isotope ratio $(0.5118)$ similar to the most differentiated Casemi samples (Table 3). The Els Metges volcanic tuff has ${ }^{143} \mathrm{Nd} /{ }^{144} \mathrm{Nd}$ ratios between 0.5117 and 0.5118 .

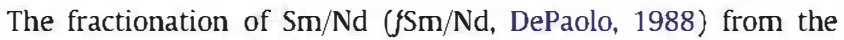
chondritic uniform reservoir (CHUR) for crustal rocks shows a narrow range of values when averaged over volumes of typical igneous source areas (Haskin and Paster, 1979; Ben Othman et al., 1984). This fractionation index can be plotted versus $\varepsilon \mathrm{Nd}_{(T)}$ to discriminate the tectonic setting (McLennan and Hemming, 1992). On such a plot (Fig. 8), all the studied samples cluster in a small area, although the Els Metges volcanic tuff and the Cadi orthogneisses are slightly more fractionated from CHUR than the Casemi orthogneiss. The Pyrenean samples have also been plotted on Fig. 8, together with an average for Early Ordovician igneous protoliths from the Central Iberian zone of the Iberian massif, ten orthogneisses from Guadarrama and five Ollo de Sapo metavolcanic rocks (data from Castro et al., 2003; Villaseca 


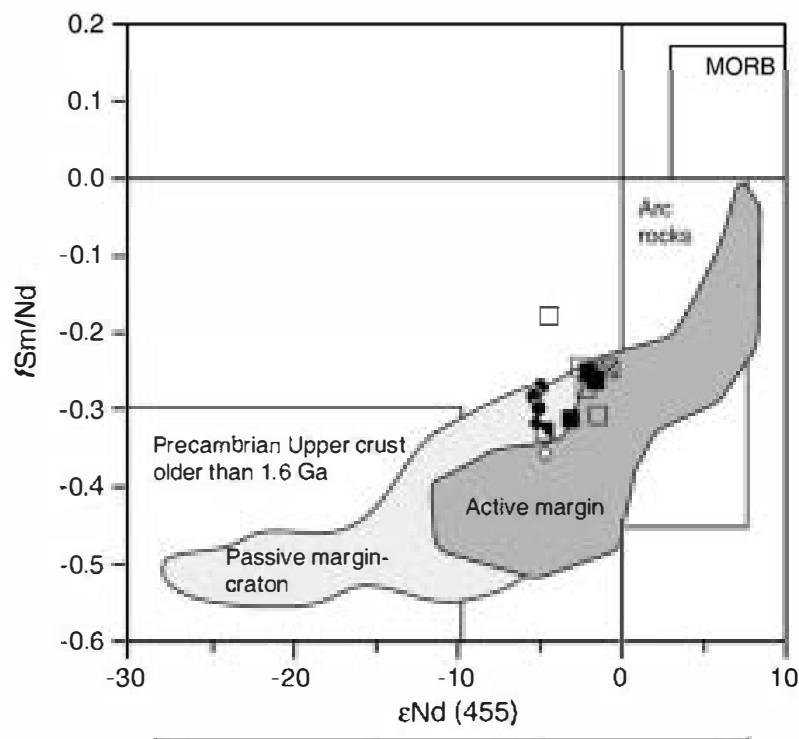

\begin{tabular}{|c|c|}
\hline 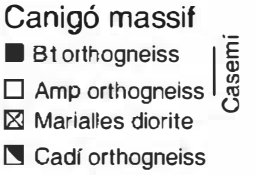 & $\begin{array}{l}\text { Les Gavarres massif } \\
\text { Els Metges volcanic tuft } \\
\text { Other samples } \\
\text { Ollo de Sapo }(\mathrm{ClZ}) \\
\text { Guadarrama }(\mathrm{ClZ})\end{array}$ \\
\hline
\end{tabular}

Fig. 8. $f \mathrm{Sm} / \mathrm{Nd}$ vers $11 \mathrm{~s} \varepsilon \mathrm{Nd}_{(455)}$ diagram for the analyzed samples showing fields used to discriminate tectonic setting (McLennan and Hemming, 1992).

et al., 1998; and unpublished data). All data have been corrected assuming an age of $455 \mathrm{Ma}$.

The uniformity in the $\int \mathrm{Sm} / \mathrm{Nd}$ and $\varepsilon \mathrm{Nd}$ values suggests a common or similar composition of the crustal source for all of the samples. Furthermore, samples of crustal provenance (such as the Els Metges tuff, and the Cadí and Guadarrama orthogneisses) plot within the passive margin area, whereas samples with a juvenile signature (such as the Casemi orthogneiss and the Marialles metadiorite) plot along the boundary between the passive and active margin areas, which is also where the Ollo de Sapo volcanic tuff plots. These results suggest a transitional tectonic setting between an active margin (Casemí orthogneiss) and a passive margin (Els Metges tuff).

Epsilon neodymium ( $\varepsilon \mathrm{Nd}$ ) values are negative in all of the samples. In the Canigó massif, the most depleted value $(-0.6)$ is displayed by the Marialles metadiorite, whereas values range between -1.2 and -4.0 in the orthogneiss samples. The Els Metges volcanic tuff has the most enriched $\varepsilon N d$ values, between -4.8 and -5.2 . In an age versus $\varepsilon N d$ diagram (Fig. 9), most of the Nd evolution lines intersect the depleted mantle curve at ages $\left(T_{\mathrm{DM}}\right)$ ranging from 1.3 to $1.7 \mathrm{Ga}$, although two samples from the Canigó massif yield $T_{\mathrm{DM}}$ ages of 2.0 and $2.2 \mathrm{Ga}$. The significance of these Mesoproterozoic $T_{\mathrm{DM}}$ ages is difficult to evaluate in igneous felsic rocks without additional supporting data (e.g., zircon inheritance) and will be discussed in the following section.

\section{Discussion}

Whole-rock geochemis shows that the orthogneiss samples from the Canigó massif are compositionally uniform. As fractionation processes cannot be recognized, crustal contamination of mantle melts is the most probable process accounting for the formation of the various analyzed lithologies (biotite and amphibole orthogneisses, and metadiorite). By contrast, in the Les Gavarres massif, the negative trends of the samples suggest that the epiclastic ash resulted from the fractionation of the rhyolitic tuff. However, given the marked depletion of mobile elements (e.g., $\mathrm{Na}_{2} \mathrm{O}$ and $\mathrm{Rb}$ ), post-depositional

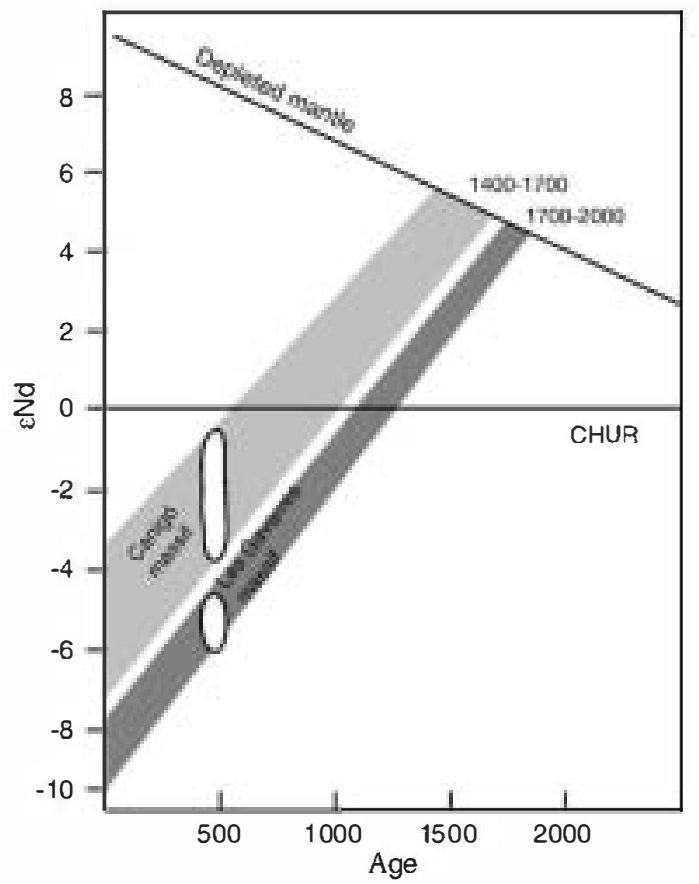

Fig. 9. Age versus end diagram for the Canigó and Les Gavarres massifs. Nd evolution lines are shown in grey.

processes could also have modified the composition of the epiclastic ash.

$\mathrm{Nd}$ isotopes suggest that the rocks originated in an active margin. In this setting, the composition of mantle-derived melts is strongly influenced by the crust, giving rise to negative $\varepsilon \mathrm{Nd}$ values (from -1 to -4.8$)-$ high negative $\varepsilon N d$ values $(-3$ to -4$)$ suggesting considerable crustal contamination. The isotopic signature of the Casemi gneiss ( $\varepsilon \mathrm{Nd}$ between -1.4 to -4 ) and the Marialles metadiorite $(\varepsilon \mathrm{Nd}=-0.6)$ indicates that their protoliths were derived from mantle melts with no uniform crustal contamination. In contrast, the higher $\varepsilon N d$ negative values $(-4.2$ to -5.2$)$ of the Cadi orthogneiss and Els Metges volcanic rocks indicate a crustal origin.

Nd model ages $\left(T_{\mathrm{DM}}\right)$ for most of the rocks are similar to those in samples from the Iberian massif (Fernández-Suárez et al., 2000; Castro et al., 2003; Rodríguez Alonso et al., 2004; Gutiérrez Alonso et al., 2005; Murphy et al., 2008a). However, the strong crustal influence on the $\varepsilon N d$ values for felsic rocks rules out an unequivocal interpretation of the $T_{\mathrm{DM}}$ ages. Recent geochronological studies in the Pyrenean massifs have reported Pan-African (800 Ma), Mesoproterozoic ( $1.0 \mathrm{Ga}$ ), Eburnean (1.8 to $2.0 \mathrm{Ga}$ ) and Archean (2.5 to $3.1 \mathrm{Ga}$ ) ages in inherited zircons from Neoproterozoic-Early Cambrian and Early Ordovician igneous rocks (Cocherie et al., 2005; Castiñeiras et al., 2008). The absence of 1.4-1.7 Ga inherited zircons suggests that the $T_{\mathrm{DM}}$ ages obtained in this study are the result of a mixture of an old component (probably Eburnean) and juvenile mantle melts (Ordovician). This favours a Neoproterozoic source mixed with Paleoprotherozoic components as the probable source for the melts that resulted in the Els Metges volcanic rocks, the Cadi aluminous orthogneiss and the source of contamination in the Casemi metaluminous orthogneiss. Moreover, the similarity of the isotopic signatures of some of the Early Ordovician aluminous magmatic protoliths of the Iberian massif (such as the Ollo de Sapo volcanic Formation and the Guadarrama orthogneisses) suggests the repeated extraction of crustal melts from a common source during the Ordovician as previously proposed (e.g., Fernández-Suárez et al., 2000). This crustal recycling would account for the volcanic arc signature of the samples. This signature was probably inherited by melting of pre-existing NeoproterozoicEarly Paleozoic calk-alkaline crust. Crustal recycling has been invoked 
to explain the volcanic arc affinity of the Early Ordovician Ollo de Sapo magmatic rocks (Díez Montes et al., 2010-this issue).

The age obtained for the Les Gavarres volcanic rocks ( $455.2 \pm 1.8 \mathrm{Ma}$ ) is equivalent to the age of crystallization of the magmatic protoliths of the Canigó gneisses (Cadí and Casemí gneiss, and Marialles metadiorite 456$446 \mathrm{Ma}$, Casas et al., 2010-this issue). Thus, the Les Gavarres volcanic rocks can be regarded as the volcanic equivalent of coeval Iate Ordovician plutonic rocks.

In the Pyrenees, this Late Ordovician magmatic event can be distinguished from the Early Ordovician event (477 and $467 \mathrm{Ma}$ ) that gave rise to the protoliths of large gneissic bodies such as AstonHospitalet, Canigó, Roc de Frausa and Albera (Castiñeiras et al., 2008; Denele et al., 2009; Liesa et al., in press). Hence, two different Ordovician magmatic episodes can be identified: an Early Ordovician magmatism that does not seem to be related to any deformational or metamorphic episode, and a Late Ordovician episode, which is coeval with normal fault development. These two magmatic events are separated by a compressional episode, probably of mid-Ordovician age (Casas, in press), that is at odds with a continuous extensional regime related to the opening of the Rheic or the Rheic and Paleotethys oceans during the Ordovician and Silurian (e.g. Nance et al., 2010-this issue). This evolution differs from that observed in the rest of the Iberian Massif, where thick (up to $4500 \mathrm{~m}$ ) Early Ordovician detrital sediments were deposited coevally with volcanism and plutonism (Pérez-Estaún et al., 1990; Valverde-Vaquero et al., 2005; Diez Montes et al., 2010-this issue), Late Ordovician magmatic activity is scarce (Valverde-Vaquero et al., 2007), and evidence of Ordovician deformation is limited (Martínez Catalán et al., 1992).

By contrast, Late Ordovician ages have also been obtained for magmatic rocks in several massifs of the Mediterranean realm: French Massif Central (Pont de Larn orthogneiss: $456 \pm 3$ Ma and Gorges d'Heric orthogneiss: $450 \pm 6 \mathrm{Ma}$, Roger et al., 2004), Sardinia (Tanaunella orthogneiss: $458 \pm 7 \mathrm{Ma}$ and Lodè orthogneiss: $456 \pm 14 \mathrm{Ma}$, Helbing and Tiepolo, 2005) and Sicily (felsic porphyroids, 456-452 Ma, Trombetta et al., 2004). Late Ordovician (450-430 Ma) granitoids with an arc signature are also distributed in a longitudinal zone across all the Alpine realms (Zurbriggen et al., 1997; von Raumer, 1998) and in the Southern Alps. Bellieni and Sassi (1981) proposed an "Upper Ordovician rhyolitic plateau" formed by a granite-rhyolite association related to an anorogenic event favoured by extension. Late Ordovician (450-420 Ma, $\mathrm{Rb}-\mathrm{Sr}$ isochron) crustal anatectic magmatism comprising tonalite to granite bodies of calc-alkaline composition and cogenetic acid tuffs have been described in the Eastem Alps, (Sassi and Zirpoli, 1979; Heinisch, 1981), and a 450-460 Ma magmatic event has also been reported in Penninic (Guillot et al., 2002) and Central Swiss Alps (Schaltegger et al., 2003).

In addition, the occurrence of a mid-Ordovician tectono-metamorphic event also appears to be characteristic of the eastern part of the northem Gondwana margin. In the Alps (Sesia Zone), a mid-Ordovician compressional event associated with amphibolite facies metamorphism has been reported by Zurbriggen et al. (1997) and Handy et al. (1999). High-pressure metamorphism in the Aar Massif (468 Ma, Schaltegger et al.,2003) and in the Southern Alps (457 \pm 5 Ma,Franzand Romer,2007) also provides evidence of an Ordovician orogenic cycle subsequently overprinted by Variscan deformation. This suggests that the Pyrenees and the Catalan Coastal Ranges were probably located in a different position on the northern Gondwana margin from that occupied by the rest of the Iberian Massif, and that both areas evolved differently following the Early Ordovician birth of the Rheic Ocean. In the Pyrenees and the Catalan Coastal Ranges, Late Ordovician magmatic activity was likely triggered by extensional tectonics affecting a previous thickened crust. This evolution supports the proposal of Stampfli et al. (2002) and von Raumer et al. (2002), who suggested that the Iate Ordovician extensional regime resulted from the collapse of a short-lived cordillera that formed during the mid-Ordovician. This cordillera, formed during a transient mid-Ordovician orogenic pulse started to collapse in a setting dominated by the Gondwana-directed subduction of a former periGondwanan ocean.

\section{Conclusions}

Late Ordovician magmatism (ca. $455 \mathrm{Ma}$ ) in the northeastern Iberian Variscan massifs is represented by metaluminous and aluminous metagranites and metadiorites, and by sequences of calcalkaline metavolcanic rocks. The metaluminous metagranites were derived from juvenile mantle melts contaminated by crustal melts, whereas the aluminous metagranites and calc-alkaline metavolcanic rocks originated from crustal melting. This Late Ordovician magmatic event differs from the Early Ordovician event that gave rise to the large gneissic bodies (Aston-Hospitalet, Canigó, Roc de Frausa and Albera gneisses) that form the core of the Eastern Pyrenean metamorphic massifs. The emplacement of the volcanic and plutonic bodies was coeval with the development of extensional tectonics.

A recycled Neoproterozoic-Early Paleozoic crust with a Paleoproterozoic signature and calk-alkaline affinity constitutes the most probable source of the crustal melts. Successive extraction of crustal melts from equivalent sources during the Ordovician would account for the geochemical similarities between the Early Ordovician and Late Ordovician magmatic rocks of the Iberian massif, the Pyrenees and the Catalan Coastal Range.

The evolution suggests that the Pyrenees and the Catalan Coastal Ranges were located in different positions on the northern Gondwana margin than those occupied by the Iberian Massif, and that both areas evolved differently following the Early Ordovician birth of the Rheic ocean.

\section{Acknowledgements}

This work was supported by the Spanish Commission for Science and Technology, project CGL-2007-66857C02-02.JMC acknowledges the support of the project Consolider-Ingenio 2010 programme, under CSD2006-00041 “Topoiberia". Some of the analyses were funded by the Petrology Department of the Paris VI and Complutense (Madrid) universities. MN acknowledges Professor G. Guitard for his introduction to the study of the Canigó massif and his help in the transfer of samples, and the Paris VI University for analytical support. The detailed comments of Damian Nance, Gabriel Gutiérrez-Alonso and two anonymous referees greatly enhanced the original version of the manuscript. George von Knorring improved the English language.

\section{Appendix A. Supplementary data}

Figure S1.

Figure S2.

Note: The supplementary material accompanying this article is available at doi:10.1016/j.gr.2009.11.013.

\section{References}

Autran, A., Fonteilles, M., Guitard, G., 1970. Rélations entre les intrusions de granitoides, l'anatexie, et le métamorphisme régional considerées principalment du point de vue de l'eau: cas de la Chaine hercynienne des Pyrénées Orientales. Bulletin Societé Géologique de France 7, 673-731.

Ayora, C, Casas, J.M., 1986. Stratabound As-Au mineralization in pre-Caradocian rocks form the Vall de Ribes, Eastern Pyrenees, Spain. Mineralium Deposita 21, 278-287.

Barnolas, A., Garcia-Sansegundo, J., 1992. Caracterización estratigráfica y estructural del Paleozoico de Ies Gavarres (Cadenas Costero Catalanas, NE de España). Boletin Geológico y Minero 103, 94-108.

Bellieni, G., Sassi, F.P., 1981. In: Karamata, S., Sassi, F.P. (Eds.), New chemical data and a review on the South-Alpine "Pre-Hercynian Rhyolitic Plateau" in the Alps: IGCP no 5, Newsletter, vol. 3, pp. 22-27.

Ben Othman, D., Polve, M., Allegre,C. J., 1984. Nd-Srisotopic composition of granulites and constraints on the evolution of the lower continental crust. Nature 307, 510-515. 
Brown, C.G., Thorpe, R.S., Webb, P.C., 1984. The geochemical characteristics of granitoids in contrasting arcs and comments on magma sources. Journal of the Geological Society of London 141, 413-426.

Calvet, P., Lapierre, H., Charvet, J., 1988. Diversitê du volcanisme Ordovicien dans la région de Pierrefitte (Hautes-Pyrénées): rhyolites calco-alcalines et basaltes alcalins. Comptes Rendus de I'Acadèmie des Sciences de Paris 307, 805-812.

Carignan, J., Hild, P., Mevelle, G., Morel, J., Yeghicheyan, D., 2001. Routine analyses of trace elements in geological samples using flow in jection and low pressure on-line liquid chromatography coupled to ICP-MS; a study of geochemical reference materials BR, DR-N, UB-N, AN-G and GH. Geostandards Newsletter 25, 187-198.

Casas, J.M, 1984. Estudi de la deformació ens els gneiss del massis del Canigó. Ph.D. thesis, Barcelona University.

Casas, J.M., in press. Ordovician deformations in the Pyrenees: new insights into the significance ofPre-Variscan ("Sardic") tectonics. Geological Magazine. doi: 10.1017/ S0016756809990756.

Casas, J.M., Fernández, O., 2007. On the Upper Ordovician unconformity in the Pyrenees: new evidence from the Ia Cerdanya area. Geologica Acta 5, 193-198.

Casas, J.M., Domingo, F., Poblet, J., Soler, A., 1989. On the role of Hercynian and Alpine Thrusts in the Upper Paleozoic rocks of the Central and Eastern Pyrenees. Geodinamica Acta 3, 135-147.

Casas, J.M., Castiñeiras, P., Navidad, M., Liesa, M., Carreras, J., 2010. New insights into the Late Ordovician magmatism in the Eastern Pyrenees: U-Pb SHRIMP zircon data from the Canigo massif. Gondwana Research 17 (2-3),317-324 (this issue).

Casini, L, Oggiano, G., 2008. Iate orogenic collapse and thermal doming of the northern Gond wana margin incorporated in the Variscan Chain: a case study from the Ozieri Metamorphic Complex, northern Sardinia, Italy. Gondwana Research 13, 396-406.

Castiñeiras, P., Navidad, M., liesa, M., Carreras, J., Casas, J.M., 2008. U-Pb zircon ages (SHRIMP) for Cadomian and Lower Ordovician magmatism in the Eastern Pyrenees: new insights in the pre-Variscan evolution of the northern Gondwana margin. Tectonophysics $461,228-239$.

Castro, A., Corretge, LG., de la Rosa, J., Fernández, C., López, S., Garcia Moreno, O. Chacón, H., 2003. The appinite-migmatite complex of Sanabria, NW Iberian Massif Spain. Journal of Petrology 44, 1309-1344.

Cavet, P., 1957. Le Paléozöique de la zone axiale des Pyrênées orientales françaises entre le Rousillon et I'Andorra (étude stratigraphique et paléontologique). Bulletin Service Carte Gêologique de France 55 (254), 303-518.

Chen, F., Hegner, E., Todt, W., 2000. Zircon ages and Nd isotopic and chemical compositions of orthogneisses from the Black Forest, Germany. Evidence for a Cambrian magmatic arc. International Journal of Earth Sciences 88, 791-802.

Cocherie, A., Baudin, Th., Autran, A., Guerra, C, Fanning, C. M., Laumonier, B., 2005. U-Pb zircon (ID-TIMS and SHRIMP) evidence for the Early Ordovician intrusion of metagranites in the late Proterozoic Canaveilles Group of the Pyrenees and the Montagne Noire (France). Bulletin Societé Géologique de France 176, 269-282.

Crowley, Q.G., Floyd, P.A., Winchester, J.A., Franke, W., Holland, J.G., 2000. Early Palaeozoic rift-related magmatism in Variscan Europe: fragmentation of the Armorican Terrane Assemblage. Terra Nova 12, 171-180.

Delaperrière, E., Soliva, J., 1992. Détermination d'un age Ordovicien supérieur - Silurien pour les gneiss de Casemi (Massif du Canigou, Pyrénées orientales) par la méthode d'êvaporation de plomo sur monozircon. Comptes Rendus de I'Acadèmie des Sciences de Paris 314, 345-350.

Deloule, E., Alexandrov, P., Cheilletz, A., Iaumonier, B., Barbey, P., 2002. In-situ U-Pb zircon ages for Early-Ordovician magmatism in the eastern Pyrenees, France: the Canigou orthogneisses. International Journal of Earth Sciences 91, 398-405.

Denele, Y., Barbey, P., Deloule, E., Pelleter, E., Olivier, Ph., Gleizes, G., 2009. Middle Ordovician $\mathrm{U}-\mathrm{Pb}$ age of the Aston and Hospitalet orthogneissic laccoliths: their role in the Variscan evolution of the Py renees. Bulletin Societé Géologique de France 180, 209-221.

DePaolo, D.J., 1988. Neodymium Isotope Geochemistry. Springer-Verlag, Berlin.

Diez Montes, A., Martinez Catalán, J.R., Bellido Mulas, F., 2010. Role of the Ollo de Sapo massive felsicvolcan ism of NW Iberia in the Early Ordoviciandynamics of northern Gondwana. Gondwana Research 17 (2-3), 363-376 (this issue).

Domingo, F., Muñoz, J.A., Santanach, P., 1988. Estructures d'encavalcament en les materials del sòcol hercinia del massis de la Tossa d'Alp. Pirineu oriental. Acta Geologica Hispanica 23, 141-153.

Evensen, N.M., Hamilton, P.J., O'Nions, R.J., 1978. Rare earth abundances in chondritic meteorites. Geochimica Cosmochimica Acta 42, 1199-1212.

Fernández-Suárez, J., Gutiérrez Alonso, G., Jenner, G., Tubret, M., 2000. New ideas on the Protherozoic-Early Paleozoic evolution of NW Iberia: insights from U-Pb detrital zircon ages. Precambrian Research 102, 185-206.

Finger, F., Hanzl, P., Pin, C, von Quadt, A., Steyrer, H.P., 2000. The Brunovistulian: Avalonian Precambrian sequence at the eastern end of the Central European Variscides? In: Franke, W., Haak, V., Oncken, O., Tanner, D. (Eds.), Orogenic Processes. Quantification and Modelling in the Variscan Belt: Geological Society of London, Special Publication, vol. 179, pp. 103-112.

Finney, S., 2005. Global series and stages for the Ordovician System. A progress report. Geologica Acta 3, 309-316.

Franz, L, Romer, R.L, 2007. Caledonian high-pressure metamorphism in the StronaCeneri-Zone (Southern Alps of southern Switzerland and northern Italy). Swiss Journal of Geosciences 100, 457-467.

Garcia-Sansegundo, J., Gavaldá, J., Alonso, J.L, 2004. Preuves de la discordante de l'Ordovicien supérieur dans la zone axiale des Pyrênées: exemple de döme de la Garona (Espagne, France). Comptes Rendus Geosciences 336, 1035-1040.

Gebauer, D., 1993. Intra-grain zircon dating within the Iberian massif: Ollo de sapo Augengneiss, bimodal gneisses from the Massif de Guilleries (Girona), Graywacke of the Tentudia Group (Serie Negra, Sw Spain) and the HP/HT rock association at Cabo Ortegal (Galicia). XII Reuniao de Geologia do Oeste Peninsular Comunicaçoes. Evora 2, 41-46.
Guillot, F., Schaltegger, U., Bertrand, J.M., Deloule, E., Baudin, T., 2002. Zircon U-Pb geochronology of Ordovician magmatism in the polycyclic Ruitor Massif (Internal W-Alps). International Journal of Earth Sciences 91, 964-978.

Guitard, G., 1953. La structure du massif du Canigou. Bulletin Societê Géologique de France 3, 907-924.

Guitard G, 1962 Sur l'existence de plis "antéschisteux"dans le Paléozo îque inférieur et les gneiss du massif du Canigou-Carança (Pyrénées Orientales). Bulletin de la Sociêté Géologique de France. Compte Rendu Sommaire des Séances de la Sociêtê Gêologique de France 4, 82

Guitard, G., 1970. Le mêtamorphisme hercynien mésozonal et les gneiss oeillês du massif du Canigou (Pyrênées-Orientales). Mêmoire Bureau Recherches Géologiques et Minières 63.

Gutiêrrez Alonso, G., Fernández Suárez, J., Collins, A.S., Abad, I., Nieto, F., 2005. Amazonian Mesoprotherozoic basement in the core of the Ibero-Armorican Arc: ${ }^{40} \mathrm{Ar}{ }^{\beta 9} \mathrm{Ar}$ detrital mica ages complement the zircon's tale. Geology 33, 637-640.

Gutiêrrez Marco, J.C., Robardet, M., Rábano, I., Sarmiento, G.N., San Josê Iancha, M.A., Herranz Arau jo, P., Pieren Pidal, A.P., 2003. Ordovician. In: Gibbons, W., Moreno, T. (Eds.), The Geology of Spain. The Geological Society, London, pp. 31-49.

Handy, M.R., Franz, L, Heller, F., Janott, B., Zurbriggen, R., 1999. Multistage accretion and exhumation of the continental crust (Ivrea crustal section, Italy and Switzerland). Tectonics 18, 1154-1177.

Hartevelt, J.A., 1970. Geology of the Upper Segre and Valira valleys, Central Pyrenees, Andorra/Spain. Leidse Geologische Mededelingen 45, 167-236.

Haskin, L.A., Paster, T.P., 1979. Geochemistry and mineralogy of the rare earths. In: Gschneidner, K.A. (Ed.), Handbook on the Physics and Chemistry of the Rare Earths. North-Holland, Amsterdam.

Hastie, A.R., Kerr, A.C., Pearce, J.A., Mitchell, S.F., 2007. Classification of altered volcanic island arc rocks using immobile trace elements: development of the $\mathrm{Th}-\mathrm{Co}$ discrimination diagram. Journal of Petrology 48, 2341-2357.

Heinisch, H., 1981. Preliminary report on Early Paleozoic acidic volcanism in the Eastern and Southern Alps - a review. In: Karamata, S., Sassi, F.P. (Eds.), IGCP no 5: Newsletter, voL 3, pp. 80-88.

Helbing, H., Tiepolo, M., 2005. Age determination of Ordovician magmatism in NE Sardinia and its bearing on Variscan basement evolution. Journal Geological Society Iondon 162, 689-700.

Jacobsen, S.B., Wasseburg, G.J., 1980. Sm-Nd isotopic evolution of chondrites. Earth and Planetary Science Letters $50,139-155$

Jaffey, A.H., Flynn, K.F., Glendenin, L.E., Bentley, W.C., Essling, A.M., 1971. Precision measurement of half-lives and specific activities of ${ }^{235} \mathrm{U}$ and ${ }^{238} \mathrm{U}$. Physical Review $\mathrm{C}$ 4 (5), 1889-1906

Julivert, M., Durán. H., 1992. El Paleozoico inferior de las Cadenas Costero Catalanas. In: Gutiêrrez Marco, J.C., Saavedra, J., Rábano, I. (Eds.), Paleozoico Inferior de IberoAmérica. Universidad de Extremadura, pp. 607-613.

Liesa, M., Carreras, J., Castiñeiras, P., Casas, J.M., Navidad, M., Vilà, M., in press. U-Pb zircon age of Ordovician magmatism in the Albera Massif (Eastern Pyrenees). Geologica Acta.

Ludwig, K.R., 1998. On the treatment of concordant uranium-lead ages. Geochimica et Cosmochimica Acta 62, 665-676.

Ludwig, K.R., 2003. User's manual for Isoplot 3.00, a geochronological toolkit for Microsoft Excel. Berkeley Geochronology Center Special Publication 4. 74 pp.

Marti,J., Muñoz, J.A., Vaquer, R., 1986. Les roches volcaniques de I'Ordovicien supérieur de la région de Ribes de Freser-Rocabruna (Pyrénées catalanes): caractères et signification. Comptes Rendus de I'Acadèmie des Sciences de Paris 302, 1237-1242.

Martinez Catalán, J.R. Rodriguez, M.P.H., Alonso, P.V. Pérez Estalin, A., González Iodeiro, F., 1992. Lower Paleozoic extensional tectonics in the limit between the West Asturian-Leonese and Central Iberian Zones of the Variscan Fold-Belt in NW Spain. Geologische Rundschau 81, 545-560.

McLennan, S.M., Hemming, S., 1992. Samarium-neodymium elemental and isotopic systematic in sedimentary rocks. Geochimica Cosmochimica Acta 561, 2015-2050.

Melleton, J., Cocherie, A., Faure, M., Rossi, P., 2010. Precambrian protoliths and Early Paleozoic magmatism in the French Massif Central: U-Pb data and the North Gondwana connection in thewest European Variscan belt. Gondwana Research 17, 13-25.

Muñoz, J.A., Sabat, F., Santanach, P., 1983. Stratigraphic correlation form in Eastem Pyrenees. In: Sassi, F.P., Szederkenyi, V. (Eds.), IGCP No 5: Newsletter, vol. 5, pp. 102-107.

Murphy, B.J., Gutiérrez Alonso, G., Fernández Suárez, J., Braid, J., 2008a. Probing crustal and mantle lithosphere origin through Ordovician volcanic rocks along the Iberian passive margin of Gondwana. Tectonophysics 461, 166-180.

Murphy, B.J., Dostal,J., Keppie, D., 2008b. Neoprotherozoic-EarlyDevonian magmatism in the Antigonish Highlands, Avalon terrane, Nova Scotia: tracking the evolution of the mantle and crustal sources during the evolution of the Rheic Ocean Tectonophysics 461, 181-261.

Nance, R.D., Gutiêrrez-Alonso, G., Keppie,J.D., Linnemann, U., Murphy, J.B., Quesada, C. Strahan, R.A., Woodcock, N.H., 2010. Evolution of the Rheic Ocean. Gondwana Research 17 (2-3), 194-222 (this issue).

Navidad, M., Barnolas, A., 1991. El magmatismo (Ortogneises y volcanismo del Ordovicico Superior) del Paleozoico de los Catalánides. Boletin Geológioo y Minero 102, 187-202.

Navidad, M., Carreras, J., 2002. El volcanismo de la base del Paleozoico Inferior del macizo del Canigó (Pirineos Orientales). Evidencias geoquimicas de la apertura de una cuenca continental. Geogaceta 32, 91-94.

Pearce, J.A., Nigel, B., Harris, W., Tindle,A.G., 1984. Trace element discrimination diagrams for the tectonic interpretarion of granitic rocks. Joumal of Petrology 25, 956-983.

Pérez-Estaín, A., Bastida, F., Martinez-Catalán, J.R., Gutiêrrez-Marco, J.C., Marcos, A., Pulgar, J.A., 1990. West Asturias-Leonese Zone: stratigraphy. In: Dallmeyer, R.D., Martinez-Garcia, E. (Eds.), Pre-Mesozoic Geology of Iberia. Springer Verlag, Berlin, pp. 92-102. 
Pin, C., Marini, F., 1993. Early Ordovician continental break-up in Variscan Europe: Nd$\mathrm{Sr}$ isotope and trace element evidence from bimodal igneous associations of the Southern Massif Central, France. Lithos 29, 177-196.

Robardet, M., 2002. Altemative approach to the Variscan Belt in southwestern Europe: preorogenic peleobiogeographical constraints. In: Martinez Catalán, J.R., Hatcher, R.D Arenas, R., Diaz Garcia, F. (Eds.), Variscan-Appalachian Dynamics: The Building of the Late Paleozoic Basement: Geological Society of America, Special Paper, vol. 364, pp. 1- 15

Robert, J.F., Thiebaut, J., 1976. Découverte d'un volcanisme acide dans le Caradoc de la région de Ribes de Fresser (Prov. de Gerone). Comptes Rendus de I'Acadèmie des Sciences de Paris 282, 2050-2079.

Rodriguez Alonso, M.D., Peinado, M., López Plaza, M., Franco, P., Carnicero, A., Gonzalo, J.C. 2004. Neoproterozoic-Cambrian synsedimentary magmatism in the Central Iberian Zone (Spain): geology, petrology and geodynamic significance. International Joumal Earth Sciences $93,897-920$

Roger, F., Respaut, J.P., BruneI, M., Matte, Ph., Paquette, J.L, 2004. Première datation U$\mathrm{Pb}$ des orthogneiss oeillés de la zone axiale de la Montgane Noire (Sud du Massif central): nouveaux témoins du magmatisme ordovicien dans la chaîne varisque. Comptes Rendus Geoscience 336, 19-28.

Romer, R.L, Soler, A., 1995. U-Pb age and lead isotopic characterization of Au-bearing skarn related to the Andorra granite. Mineralium Deposita 30, 374-383.

Santanach, P., 1972. Estudio tectónico del Paleozoico inferior del Pirineo entre la Cerdaña y el rio Ter. Acta Geológica Hispánica 7, 44-49.

Sarmiento, G.N., Sanz-López,J., Barnolas, A., 1995. Conodontos del Ashgill en las Calizas de Madremanya, Les Gavarres (Girona). XIJornadas de Paleontologia, Tremp 161-163.

Sassi, F.P., Zirpoli, G., 1979. Pre-Variscan acidic magmatism in the Eastern Alps. IGCP no 5. Newsletter 1, 111-121.

Schaltegger, U., Abrecht, J., Corfi1, F., 2003. The Ordovician orogeny in the Alpine basement: constraints from geochronology and geochemistry in the Aar Massif (Central Alps). Schweizerische Mineralogische und Petrologische Mitteilunge 83, 183-195.

Stacey, J.S., Kramers, J.D., 1975. Approximation of terrestrial lead isotope evolution by a two-stage model. Earth and Planetary Science Letters 26, 207.

Stampfli, G.M., von Raumer, J.F., Borel, G.D., 2002. Paleozoic evolution of pre-Variscan terranes: from Gondwana to the Variscan collision. In: Martinez Catalán, J.R. Hatcher, R.D., Arenas, R., Diaz Garcia, F. (Eds.), Variscan-Appalachian Dynamics: The Building of the Late Paleozoic Basement: Geological Society of America, Special Paper, vol. 364, pp. 263-280

Steiger, R.H., Jäger, E., 1977. Subcomission on geochronology: convention on the use of decay constants in geo- and cosmochronology. Earth and Planetary Science Letters $36,359-362$.
Trombetta, A., Cirrincione, R., Corfu, F., Mazzoleni, P., Pezzino, A., 2004. Mid-Ordovician $\mathrm{U}-\mathrm{Pb}$ ages porphyroids in the Peloritan Mountains (NE Sicily): palaeogeographical implications for the evolution of the Alboran microplate. Journal of the Geological Society London 161, 265-276.

Twist, D., Harmer, R.E.J., 1987. Geochemistry of contrasting siliceous magmatic suites in the Bushveld Complex: genetic aspects and implications for tectonic discrimination diagrams. Journal of Volcanology and Geothermal Research 32, 83-98.

Valverde-Vaquero, P., Marcos, A., Farias, P., Gallastegui, G., 2005. U-Pb dating of Ordovician felsic volcanism in the Schistose Domain of the Galicia-Trás-os-Montes Zone near Cabo Ortegal (NW Spain). Geologica Acta 3, 27-37.

Valverde-Vaquero, P., Farias, P., Marcos, A., Gallastegui, G., 2007. U-Pb dating of SiluroOrdovician volcanism in the Verin synform (Orense; Schistose Domain, GaliciaTrás-os-Montes zone). Geogaceta 41, 247-250.

Villas, E., Durán, H., Julivert, M., 1987. The Upper Ordovician clastic sequence of the Catalan Coastal Ranges and its brachiopod fauna. Neues Jahrbuch für Geologie und Paläontologie Abhandlungen 174, 55-74.

Villaseca, C, Barbero, L, Rogers, G., 1998. Crustal origin of Hercynian peraluminous granitic batholiths of Central Spain: petrological, geochemical and isotopic (Sr, Nd) constraints. Lithos 43, 55-79.

von Raumer,J.F., 1998. The Paleozoic evolution in the Alps: from Gondwana to Pangea. Geologische Rundschau 87, 407-435.

von Raumer, J.F., Stampfli, G.M., Borel, G., Busy, F., 2002. Organization of pre-Variscan basement areas at the north-Gondwanan margin. International Journal of Earth Sciences $91,35-52$.

Winchester, J.A., Floyd, P.A., 1977. Geochemical discrimination of different magma series and their differentiation products using immobile elements. Chemical Geology 20, 325-343.

Wood, D.A., Joron, J.L. Treuil, M., 1979. A re-appraisal of the use of trace elements to classify and discriminate between magma series erupted in different tectonic settings. Earth and Planetary Science Letters 45, 326-336.

Zurbriggen, R., Franz, L, Handy, M.R., 1997. Pre-Variscan deformation, metamorphism and magmatism in the Strona-Ceneri Zone (southern Alps of northern Italy and southern Switzerland). Schweizerische Mineralogische und Petrologische Mitteilungen $77,361-380$.

Zwart, H.J., 1979. The geology of the Central Pyrenees. Leidse Geologische Mededelingen $50,1-74$. 